\title{
The Börzsöny lacewing collection I. (Neuroptera: Osmylidae, Mantispidae, Hemerobiidae, Chrysopidae, Nemopteridae, Myrmeleontidae: Ascalaphinae)
}

\author{
LEVENTE ÁBRAHÁM
}

H-7400 Kaposvár, P.O. Box 70, Hungary, e-mail: labraham@smmi.hu

\begin{abstract}
The entomological collection of László Börzsöny was donated to the Rippl-Rónai Museum (Kaposvár) in 2019. Osmylidae 2 exx. - 2 sp., Mantispidae 1 ex. - 1 sp., Hemerobiidae 2 exx. - 1 sp., Chrysopidae 28 exx. - 12 sp., Nemopteridae 100 exx. - 6 sp., Myrmeleontidae: Ascalaphinae 444 exx. - 68 $\mathrm{sp}$. were identified in this collection. During the identification, 3 new synonyms were revealed namely Palparidius fascipennis (Banks, 1911) (syn. n.) a new junior synonym of Palparidius capicola Péringuey, 1910, Ululodes sinuatus Banks, 1924 (syn. n.) a new junior synonym of Cordulecerus praecellens (Gerstaecker, 1885), Agrionosoma pendleburyi Fraser, 1927 (syn. n.) is a new junior synonym of Agrionosoma dohrni van der Weele, 1909. The lectotype of Suphalomitus buyssoni van der Weele, 1909 and the lectotype of Suhpalacsa donckieri Navás, 1913 were designated. Several species were found as new records for the local faunas: Dielocroce chobauti (Mclachlan, 1898) for Jordan; Ameropterus selysi (van der Weele, 1909) for Peru and French Guiana; Cordulecerus praecellens (Gerstaecker, 1885), Amoea arenosa (Walker, 1853) Haploglenius cuboides Jones sl. and Ululodes venezolensis van der Weele, 1909 (stat. n.) for Peru; Allocormodes junodi van der Weele, 1909 for Tanzania; Ascalobyas microcerus (Rambur, 1842) for Belize; Protidricerus elwesii (McLachlan, 1891) for Myanmar, Thailand and Vietnam; Tmesibasis rothschildi van der Weele, 1907 for Ethiopia; Agrionosoma dohrni van der Weele, 1909 and Agrionosoma swinhoei van der Weele, 1909 for Myanmar; Encyoposis seydeli (Navás, 1929) for Zambia; Glyptobasis cornuta Kimmins, 1949 for Nepal; Libelloides sibiricus (Eversmann, 1850) for Mongolia; Maezous tomijankae Ábrahám, 2008 for China and Vietnam; Malesianus harisi (Ábrahám, 2008) for Indonesia; Nephoneura costalis van der Weele, 1909 for Zambia, Ghana, Cameroon; Phalascusa vassei van der Weele, 1909 for Kenya. Zambia, Namibia and Suphalomitus formosanus Esben-Petersen, 1913 for Vietnam.
\end{abstract}

Keywords: Börzsöny lacewing collection, new synonym, faunistic data

\section{Introduction}

The insect collection of Mr. László Börzsöny, who passed away in 2017, was donated by his widow to the Rippl-Rónai Museum (Kaposvár) in 2019.

The collection of approximately 8,000 specimens consists mainly of dragonflies and damselflies, but also includes a smaller number of other groups of insects (lacewings, butterflies, beetles, etc. The collection also includes a large number (1,057 specimens) of antlions and owlflies from Europe, Asia, Africa and South America.

László Börzsöny (Fig. 1) was born in Pécs in 1942. He spent his childhood in Dunaszekcső and Érd (Hungary). Already at a young age, he came very close to nature. His initial beetle collecting trips were supported by his nature lover grandfather.

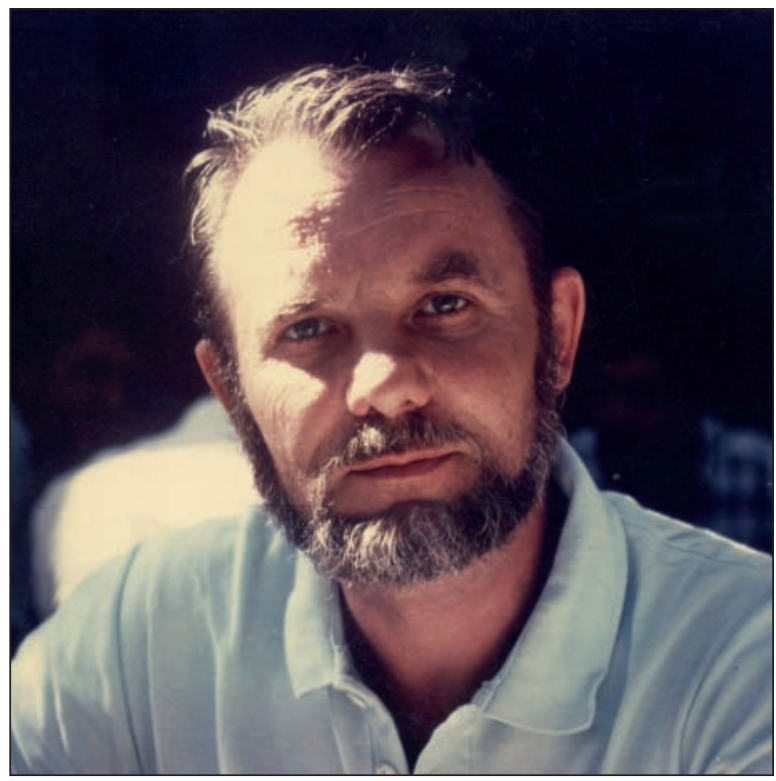

Fig. 1. László Börzsöny (1942-2017)

During his pupil's years, his family moved to Budapest, where he completed his primary and secondary schools and graduated at the Faculty of Electrical Engineering and Informatics at Budapest University of Technology and Economics.

From 1970, he lived in Germany and then moved to South Africa with his family.

In South Africa, he initially worked at the National Institute of Metallurgy and later he worked as a research adviser assistant, at the Chamber of Mines. After five years, they returned back to Germany from South Africa. Wherever he worked or traveled in the world, he always collected his favorite and admired insects with great enthusiasm. His unquenchable interest in entomology remained throughout for all his life. During his retirement years, he returned to Hungary, again.

In his retirement years, he devoted almost all of his energy to researching dragonflies and damselflies, which resulted in the establishment of a huge and valuable collection of these insects. He was also interested in aquaristics, propagating special plants, collecting cacti and nature photography.

Unfortunately, he was attacked by a fatal disease in 2016 and died in 2017. 


\section{Material and methods}

László Börzsöny stored his collection in tightly closed plastic boxes (Fig. 2). He packed each specimen extremely precisely in transparent sachets with hard paper stiffeners (Fig. 3). Each sachet was numbered next to the name of the order and provided faunistic data with maximal care. The lacewing collection was undeterminate except for a few specimens.

After transporting the collection to the museum, the first step was to give a number to the plastic boxes. This was followed by the determination of numbered specimens packed individually in each sachet. A determination label with the name of the species, author, description year, and the name of determinator was placed into the sachets. Subsequently, the data of the numbered sachets were entered into an excel spreadsheet. If the unprepared specimens did not show the identification features, those specimens were mounted out.

Some alcohol-preserved owlfly specimens from the collection (11 specimens) were still stored in alcohol after their determination. Most species belonged to the families Myrmeleontidae, Ascalaphidae, and Nemopteridae in the traditional phylogenetic sense. A few specimens can be found in Osmylidae (2 specimens), Mantispidae (1 specimen), Hemerobiidae (2 specimens), Chrysopidae (28 specimens).
The collection also includes 43 large Megaloptera specimens from Southeast Asia and South America. We intend to involve external experts in the determination of these species in the future.

Finally, small cardboard boxes were prepared for the determined materials and stored in glass-covered insect boxes grouped by species (Fig. 4). The pinned material was also placed into insect boxes.

During the determination, I compared the material with type specimens, which are kept in the following collections:

BAUC - Beijing Agricultural University, Beijing, China

$\mathrm{BMNH}$ - The Natural History Museum, London, England

MCZC - Museum of Comparative Zoology, Harvard, Cambridge, Massachusetts

MIZ - Museum and Zoological Institute of the Polish Academy of Sciences, Warsaw

MNHN - Museum National d'Histoire naturelle, Paris, France

MRAC - Musee Royal de l'Afrique Centrale, Tervuren

OXUM - Hope Entomological Collections, University Museum, Parks Road, Oxford, England

SCMK - Rippl-Rónai Museum, Kaposvár, Hungary

ZMHB - Museum für Naturkunde der Humboldt Universität zu Berlin, Bereich Zoologisches Museum, Berlin, Germany

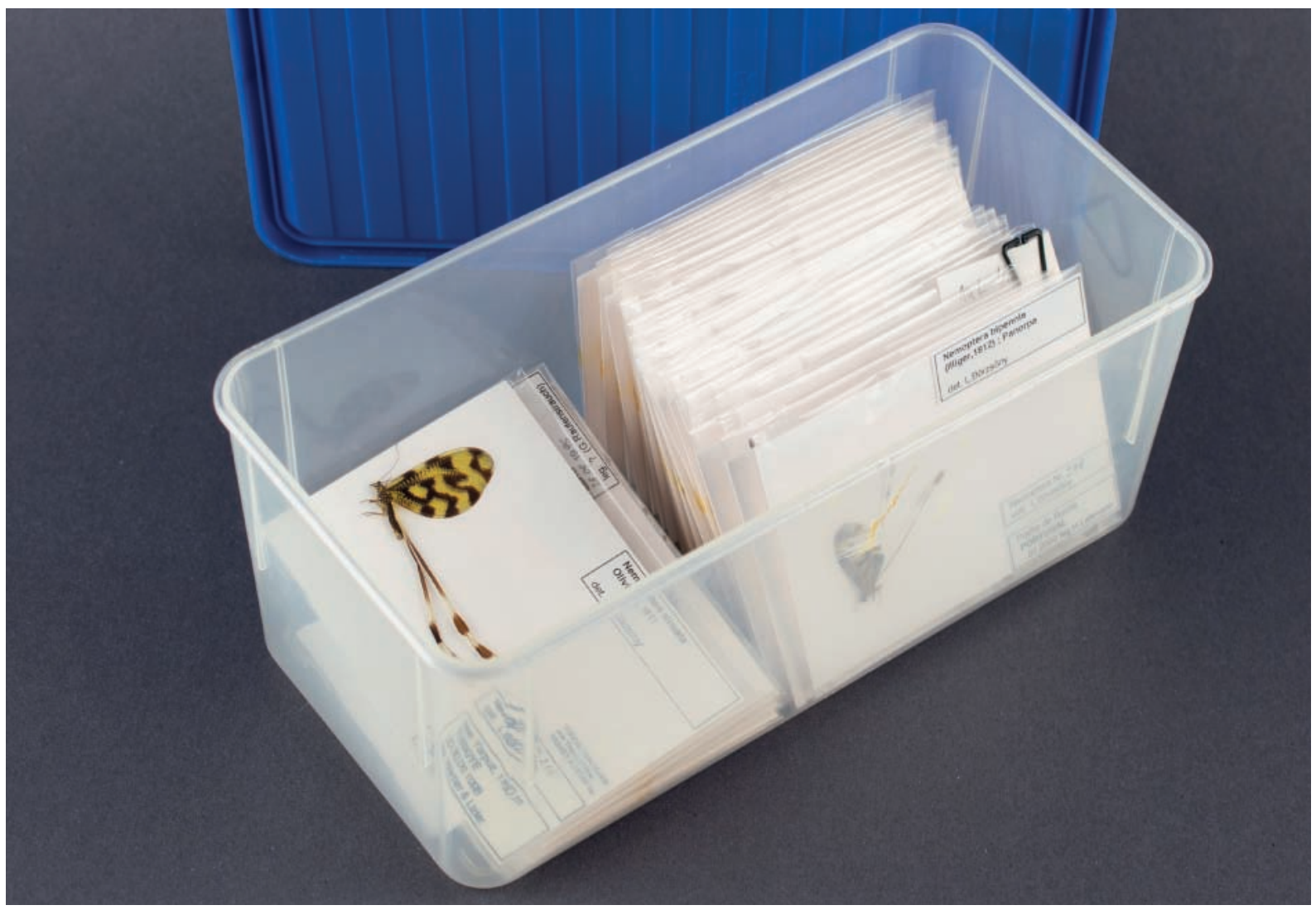

Fig. 2. Collected specimens in a plastic box 


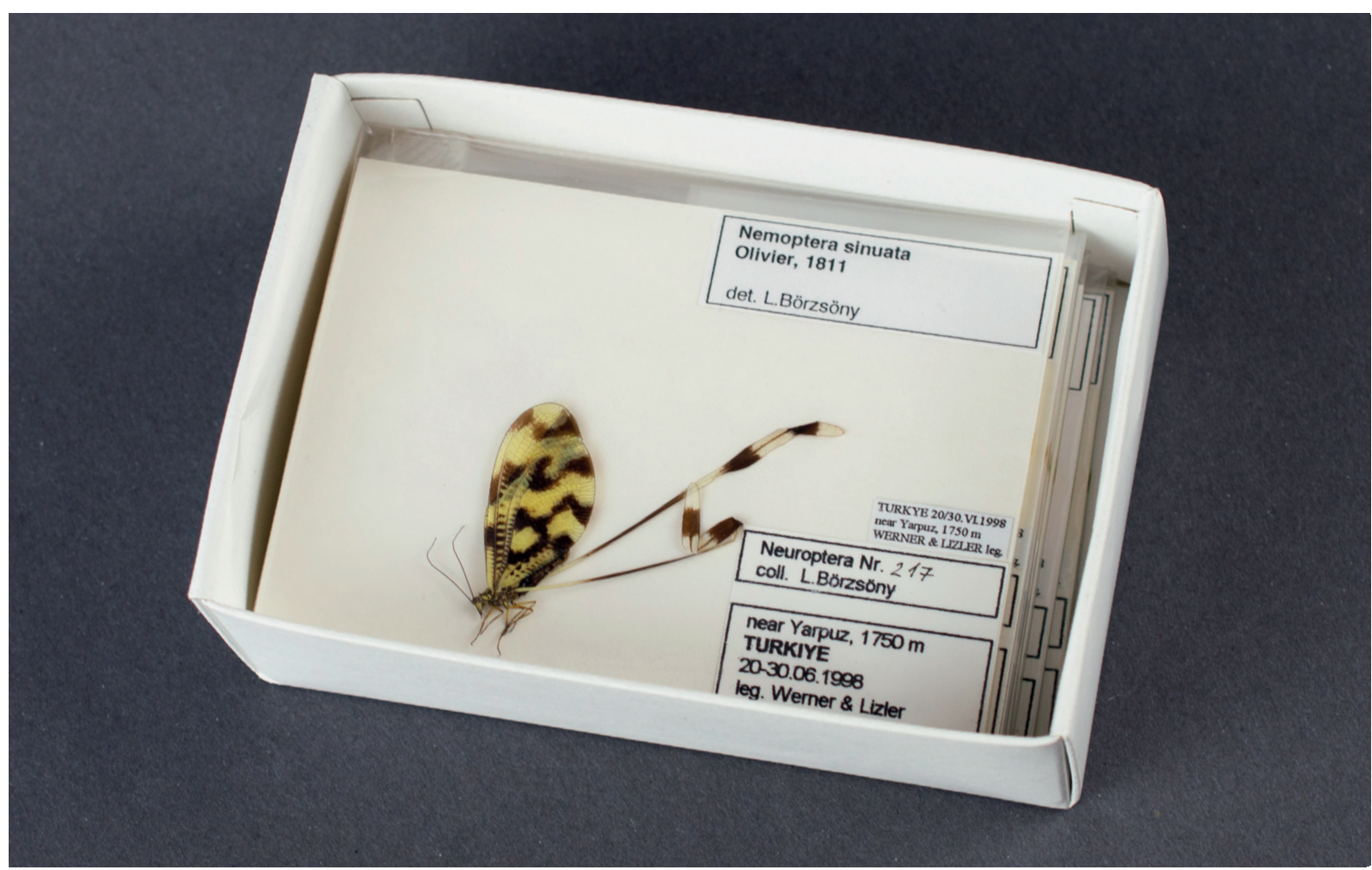

Fig. 3. Each specimen was packed extremely precisely in transparent sachets with hard paper stiffeners and with faunistic labels

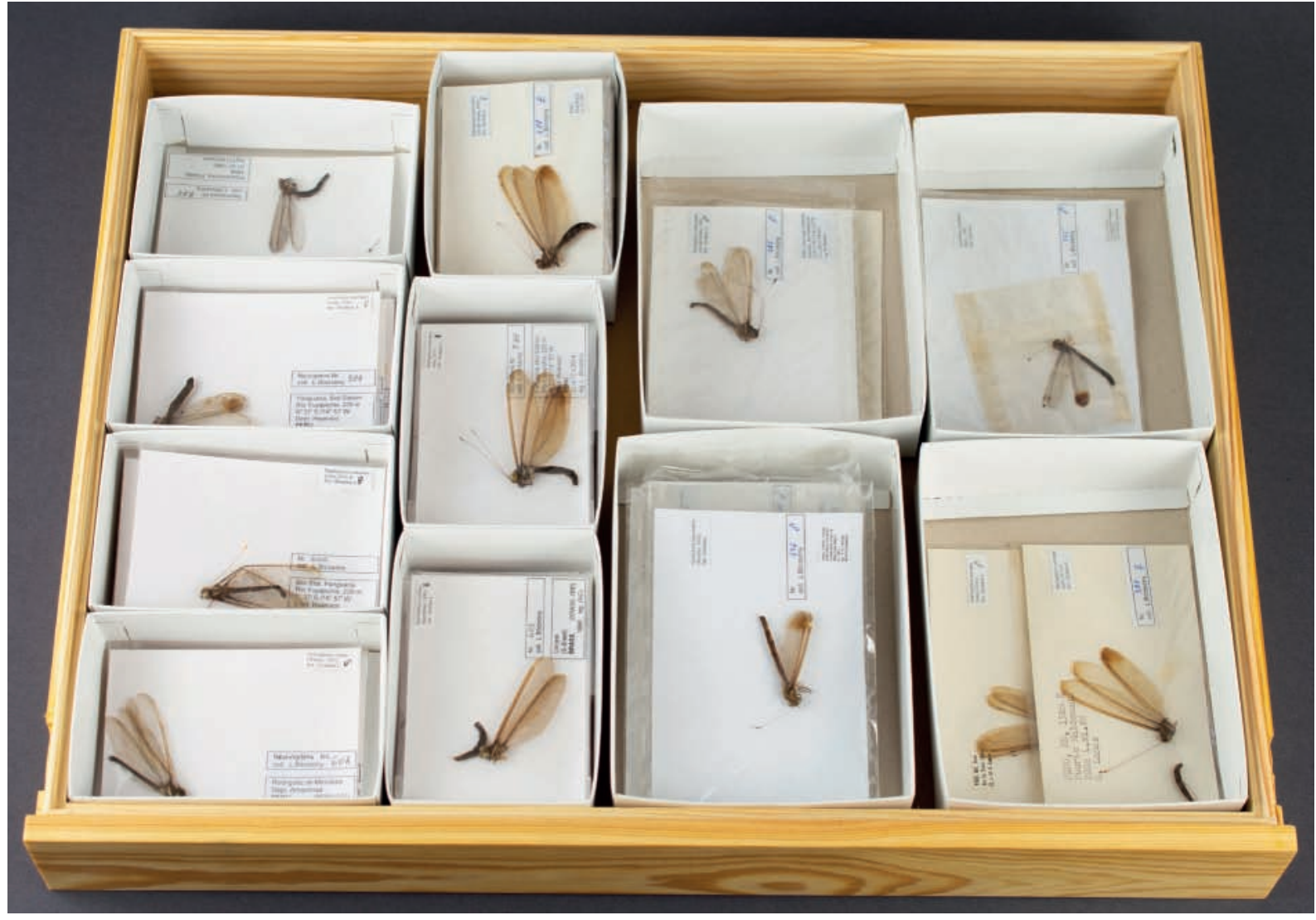

Fig. 4. Current storage in an insect box by species 


\section{Results and discussion}

Faunistic data are given on the basis of the labels in the collection in English, German and Hungarian, as they appeared on the original label. The faunistic data of each specimen were separated by semicolons. In most cases, faunistic data included sex, country, collecting site, date, and collector. Some specimens lacked tip of of the abdomen, so their sex could not be determined. I marked it with a dash ( - ) after the number of specimens.

After presenting the faunistic data of each species, a brief taxonomic, faunistic, distribution, etc. information is provided.

Descriptions of new taxa and second part of Myrmeleontidae are not included in the current paper.

Family Osmylidae Leach in Brewster, 1815

There are only 2 specimens of 2 osmylid species in the Börzsöny collection. They come from two countries (Slovenia, Turkey).

Osmylus fulvicephalus (Scopoli, 1763)

Specimen examined: 1 $\widehat{\partial}$ Slovenia River Scavnica 16.07.1997. leg. Sveti Jurij.

Remarks: A widespread species in Europe (Aspöck et al. 2001).

Osmylus multiguttatus McLachlan, 1870

Specimen examined: 1 q Turkey near Yarpuz 1700m 20-30.06.1998 leg. Werner \& Lizler.

Remarks: The recent distribution data were published by Dobosz (2007) from Turkey and also described the general distribution of the species in Europe and Asia Minor.

\section{Family Mantispidae Leach, 1815}

There was only one large-sized specimen in the collection from Kenya.

Pseudoclimaciella apicipennis (Kolbe, 1897)

Specimen examined: 1 q Kenya near Voi 28.03.1995 leg. Werner.

Remarks: A widespread species in the Subsaharan area (Handschin 1960).

Family Hemerobiidae Latreille, 1802

Only 2 specimens of 1 species can be found in the collection.

Wesmaelius navasi (Andréu, 1911)

Specimens examined: 2 ô Jordania near Aquaba 04.1999 leg. G. Müller.
Remarks: This species spreads from Morocco to Mongolia in eremic areas (Aspöck et al. 2001).

Family Chrysopidae Schneider, 1851

The chrysopid material comes from occasional sampling in the collection. Neither in the number of specimens nor in the number of species is significant. There are a total of 28 specimens of 12 species, 4 of them have not been identified at species level yet.

Nineta flava (Scopoli, 1763)

Specimen examined: 1 + Germany Haspelmoor 19.06. 1993 leg. L. Börzsöny.

Remarks: It is a widespread species in the western part of the Palearctic (Aspöck et al. 1980).

Ankylopteryx sp. 1

Specimen examined: 1 q Japan Dogamori (hillside streams) Kochi Prefecture Honshu 10.08.1993 leg. L. Börzsöny.

Remarks: 5 valid species from Japan were described in the genus (Oswald 2020). Not determined at the species level.

Chrysopa perla (Linnaeus, 1758)

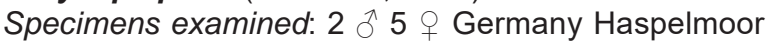
19.06. 1993 leg. L. Börzsöny.

Remarks: It is a widespread and common species in the Palearctic.

Chrysopa viridana Schneider, 1845

Specimen examined: 1 $\widehat{\partial}$ Jordania Oberes Jordantal 250m vi.1999 leg. G. Müller.

Remarks: It is found mainly in the southern part of the Western Palearctic.

Chrysopa sp. 1

Specimens examined: 3 - Jordania Oberes Jordantal vi.1999 leg. G. Müller.

Remarks: Not determined at the species level.

Chrysopa sp. 2

Specimen examined: 1 o China Hunan 6-7. 1999.

Remarks: Not determined at the species level.

Chrysopidae sp. 1

Specimen examined: 1 P Peru MD, Rio Madre de Dios, Cuzco Amazónico 10 km E Pto. Maldonado 250m 4. iv.1986 I. Bohóquez.

Remarks: Not determined at the genus and species level. 
Chrysoperla carnea (Stephens, 1836) sl. Specimens examined: $1 \hat{\delta} 1$ q Hungary Budapest, Rózsa-domb 08.04.1997 leg. L. Börzsöny.

Remarks: It is an unclear species-group from taxonomic point of views.

Pseudomallada flavifrons (Brauer, 1851)

Specimen examined: 1 o Jordania E Ghor südl. Totes Meer 250m v.1999 leg. G. Müller.

Remarks: It is a widespread species in the Palearctic.

Pseudomallada venosus (Rambur, 1838)

Specimens examined: 1 ○ Jordania E Ghor südl. Totes Meer 250m v.1999 leg. G. Müller; 9 त 1 क Jordania Oberes Jordantal 250m vi.1999 leg. G. Müller.

Remarks: The distribution of the species extends from the southern part of the Western Palearctic to Inner Asia. It is a frequent species in dry habitats.

Suarius tigridis (Morton, 1921)

Specimens examined: 2 o Jordania near Amman 1000m iv. 1999 leg. G. Müller.

Remarks: It is distributed in North Africa and Middle Asia as well as in South Spain.

Suarius walsinghami Navás, 1914

Specimens examined: 2 ô Jordania near Amman 1000m vii. 1999 leg. G. Müller.

Remarks: Its distribution is similar to the previous species.

Family Nemopteridae Burmeister, 1839

There are exactly 100 nemopterid specimens in the collection those belong to 6 species. They were collected in 6 countries, Europa: Portugal; Asia: Jordan, Iran, Turkey; Africa: South Africa, Namibia. Most of the specimens come from the same collecting sites.

\section{Subfamily Crocinae Navás, 1910}

Dielocroce chobauti (Mclachlan, 1898)

Specimens examined: 1 Jordania near Aquaba 04. 1999 leg. G. Müller; 1 స Jordania E Ghor südl. Totes Meer 250m 05. 1999 leg. G. Müller; 2 o 4 ๆordania E Ghor südl. Totes Meer 250 m 06. 1999 leg. G. Müller;

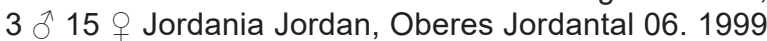
leg. G. Müller; 2 ^ 3 ㅇ Jordania Jordan, Oberes Jordantal 07. 1999 leg. G. Müller; 1 ઈ 9 Jordania near Amman 1000 m 07. 1999 leg. G. Müller.

Remarks: It is a widespread species in North Africa from Morocco (Ábrahám 2017a) to Israel (Hölzel 1975, Aspöck et al. 2001). Based on the collection imagoes are in flying from April to July and it is one of the most fre- quent thread-winged lacewings in June and July. This species is a new record for the fauna of Jordan.

\section{Subfamily Nemopterinae Burmeister, 1839}

Halter nutans Navás, 1910

Specimens examined: 1 त 3 I Iran Salt Lake near Bager Abad 2-4 week of July, 1996 leg. G. Müller.

Remarks: Recently, Ábrahám (2014) published known distribution data for the species. In southwestern Asia, it extends from Iran to India but is also found in the southeastern part of the Arabian Peninsula (Sziráki 2011: UAE, Hölzel 1999: Oman).

Nemeura tipularia (Westwood, 1874)

Specimen examined: 1 Namibia 20 km S Windhoek 01.11.1994 leg. K. Werner.

Remarks: So far, it has been found only in Namibia, it seems to be an endemic species in the area of Damaraland (Tjeder 1967).

Nemia angulata (Westwood, 1836)

Specimens examined: 1 s South Africa Porth Nolloth, $20 \mathrm{~km}$ inland, 27.10.1996 leg. Werner; 1 o South Africa Gavies 31.10.1996 leg. Werner.

Remarks: The occurrence of the species was mentioned in Tjeder's (1967) monograph from South Africa and Namibia. The endemic species inhabits extreme dry areas in the western part of southern Africa (Abdalla et al. 2019).

Nemoptera bipennis (Illiger, 1812)

Specimens examined: 9 ते 29 q Portugal Praiha de Rocha --.07.2000 leg. H. Lehmann; 2 ๙ 2 \& Portugal Algarve --.07.1997 leg. H. Lehmann.

Remarks: The distribution of the species in the Iberian Peninsula is well known (Aspöck et al. 1980). The up to date distribution map was published by Monserrat \& Triviño (2013).

Nemoptera sinuata Olivier, 1811

Specimens examined: 2 त 8 T Turkey near Yarpuz 1750 m 20-30.06.1998 leg. Werner \& Lizler

Remarks: The general distribution of the species was published by Aspöck et al. (2001). Dobosz \& Ábrahám (2009) also documented faunistic data in Turkey.

Family Myrmeleontidae Latreille, 1802

Subfamily Ascalaphinae Lefébvre, 1842

The species of the subfamily are represented in high numbers (68 species) in the collection. Surprisingly, only one species is found in Europe. The recorded specimens come from the following countries: Europe: Greece; Africa: Ethiopia, Kenya, Namibia, Tanzania; 
Asia: Myanmar, Cambodia, China, India, Indonesia, Thailand; America: Belize, Brasil, French Guiana (part of France), Mexico, Peru, USA, Venezuela.

Tribe Dimarini Navás, 1914

Millerleon subdulus (Walker, 1853)

Specimens examined: 1 P Peru Madre de Dios, Manu Park 500-800m --.2.1998 leg. NC/Lehmann; 2 đ Peru Limony, Distr. Chochamaka 1800 m ,..3-4.1999 leg. NC/ (GMU); 1 q Peru Abancay Dept. Apurimac ,..01.1999 leg. NC/(GMU); 4 ô 2 P Peru Abancay; Dept. Apurimac 2-3000 m ,..3-4.1999 leg. NC/(GMU).

Remarks: The tribe Dimarini Navás, 1914 from South America was revised by Stange (1989). During his revision, a new genus called Millerleon Stange, 1989 was described. He listed 3 species in the genus which were endemic in the desert areas of the Pacific coast. The type specimen was also found in Peru (Walker 1853). Its occurrence was also documented in Equador (Banks 1908). Dimares formosus Banks, 1908 and Dimares venustus Banks, 1908 proved to be synonyms (Stange 1989).

Tribe Palparini Banks, 1911

Annulares annulatus (Stitz, 1912)

Specimens examined: 2 ㅇ 1 - Namibia ca. $80 \mathrm{~km} \mathrm{SW}$ Windhoek 1360 m 12.1-10.2.1997 leg. H. Lehmann.

Remarks: The genus revision was performed by Mansell (2004). This species is known in Botswana, Namibia, and South Africa. An endemic species of the Kalahari Savannah (Mansell 2004). Imagoes fly from January to April.

Crambomorphus karrooanus (Péringuey, 1910) Specimens examined: 2 ก 3 q Namibia ca. 80 km NE Windhoek 4.1-4.2.1999 leg. H. Lehmann; 5 q Namibia ca 80 km SW Windhoek 1360 m 12.1-10.2.1997 leg. H. Lehmann.

Remarks: A revision of this genus was recently published by Mansell (2018). So far, it has come only from Namibia and South Africa. It lives in dry and sparsely vegetated areas and flies in January and February.

Golafrus oneili (Péringuey, 1911)

Specimens examined: 2 o Namibia ca $80 \mathrm{~km}$ SW Windhoek 1360 m 12.1-10.2.1997 leg. H. Lehmann; 1 o 10 \& Namibia Aranos 03.02.1995 leg. Werner.

Remarks: Within the tribe, the genus can be easily distinguished by very characteristic wing shape. The species inhabits arid sandy grasslands in Namibia and South Africa.

Goniocercus klugi (Kolbe, 1898)

Specimens examined: $2 \hat{\alpha} 1$ Ethiopia Sidano near Negele borana 07-08.05.1997. leg. Werner.
Remarks: It is a very diverse species from a morphological point of view. There are small-sized (FW 45-50 $\mathrm{mm}$ ) and fairly pale coloured winged specimens in the Arabian Peninsula (Klug 1836). There are large-sized (FW 57-75 mm), highly contrasting patterned winged specimens in and around the Ethiopian mountains (Stitz 1912), while there are also small-sized (FW 45$50 \mathrm{~mm}$ ) but contrasting winged specimens in the Subsaharan region (Mali). Genetic testing of the species would definitely be required. Prost (2010) figured a map of the distribution of the species.

Palparellus flavofasciatus (McLachlan, 1867)

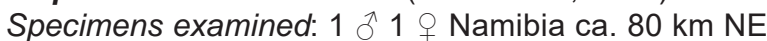
Windhoek 4.1-4.2.1999 leg. H. Lehmann.

Remarks: The genus revision and species redescription were provided by Mansell (1996). He presented its habitat (open grasslands), adult flight period (December-April) and distribution (South Angola, Namibia).

Palpares chrysopterus Navás, 1911

Specimens examined: 3 ते 2 + Iran Wadi Shur, semidesert near Hasanabad 2-4 week of July, 1996 leg. G. Müller; 6 Iran Estalak, E of Teheran, indoturanisches Grassland 2-4 week of July, 1996 leg. G. Müller.

Remarks: In contrast to Krivokhatsky et al. (2017), this is a valid taxon. At first, Navás mentioned the name of the species and gave a description as well as illustrations on a male at the "Congreso de Valencia” held in 1910. The conference proceedings was in fact published in 1911, so this date should be considered the year of publication. He had previously made a description of this species on the basis of a female specimen, but this article did not appear until 1913 (Navás 1913). Thus, the publication of Navás (1911) can be considered as the first description of the species and the later published description (Navás 1913) is only a homonymous and synonymous name.

The distribution of the species has already been outlined by Ábrahám (2012).

\section{Palpares immensus McLachlan, 1867}

Specimens examined: 34 त 2 \& Namibia Aranos 03.02.1995 leg. Werner; 6 of 12 Namibia Fish River Canyon 04.-05.02.1995 leg. Werner; 8 of 9 amibia ca 80 km SW Windhoek 1360 m 12.1-10.2.1997 leg. H. Lehmann.

Remarks: This species may be common in Namibia based on the preserved specimens of SCMK collection. The flight period of imagoes lasts from January to February. Most of the distribution data of the species are from Namibia (McLachlan 1867, Navás 1912b) or South Africa (Esben-Petersen 1916) and Southern Angola (Mansell 2002). Mansell \& Oswald (2020) cited its occurrence in Angola, Botswana, Namibia, and South Africa. Faunistic data from Kilwa [Tanzania] documented by Navás (1912a) may be incorrect. 
Palpares inclemens (Walker, 1853)

Specimens examined: 1 \% Kenya Arabuko-Sokoke forest, Mailindi 08.04.1995 leg. Werner mounted; 2 우 Kenya Malindi, Kissiwany Complex Mangoplantage 02.04.1989 leg. U. Kupka; 1 \& Kenya Malindi, Kissiwany Complex Mangoplantage 31.03.1989 leg. U. Kupka; 1 \& Kenya Malindi, Kissiwany Complex Mangoplantage 17.04.1989 leg. U. Kupka.

Remarks: Its range extends from the eastern part of South Africa to Kenya and it also inhabits in islands of Zanzibar (Tanzania) and Socotra (Yemen) (Oswald 2020).

Palpares lentus Navás, 1912

Specimens examined: 1 ते South Africa Ohrigstadt, Transvaal 08.11.1994 leg. K. Werner mounted; 1 \& RSA Transvaal Thabazimbi 06-08.11.1994 leg. Werner.

Remarks: It is an endemic species in the central and eastern provinces of South Africa (Mansell 2002).

Palpares papilionoides (Klug in Ehrenberg, 1834) Specimens examined: 1 \& Ethiopia Hirna, Harerge prov. 19.04.1998 leg. K. Werner; 1 of Ethiopia Sidano near Negele borana 07-08.05.1997 leg. Werner; 3 đ 2 Kenya Voi, Sagala Reg. 12.1994 leg. Werner, mounted.

Remarks: The distribution of the species was summarized by Prost (2010). It is widespread from the Arabian Peninsula in the Saharan and Subsaharan zones to West Africa and has abundant populations in the desert and dry savannah areas of East Africa (Kenya, Uganda, Tanzania).

Palpares sobrinus Péringuey, 1911

Specimen examined: 1 o South Africa Saltpan, N. Transvaal --.12.1995 leg. ?(NC).

Remarks: This species was collected in the northern and eastern provinces of South Africa and also found in Botswana and Zimbabwe (Mansell \& Oswald 2020). It inhabits savannah and grassland areas.

Palpares torridus Navás, 1912

Specimens examined: 1 2 ㅇ Ethiopia Bitata, Sidamo prov. 24.04.1998 leg. K. Werner; 2 Tanzania near Babati 3-6.12.1997 leg. Werner \& Lizler; 1 t 4 q Tanzania Babati, 30km to Dodoma 02.-03.12.1994 leg. Werner.

Remarks: The valid distribution data are known from the eastern half of Africa (Navás 1912d, Whittington 2002: Tanzania, Navás 1909-1915: Zambia, EsbenPetersen 1931: Ethiopia).

\section{Palparidius capicola Péringuey, 1910}

Specimens examined: 6 ก 8 은 Namibia ca. 80 km SW Windhoek $1360 \mathrm{~m}$ 12.1-10.2.1997 leg. H. Lehmann; 5 त 10 Namibia ca. 80 km NE Windhoek 4.14.2.1999 leg. H. Lehmann; 2 Namibia Hardap Dam 06.02.1995 leg. Werner mounted; 1 \&amibia 10 km E Stampriet 06.02.1995 leg. Werner; 1 ô Namibia Fish River Canyon 04-05.02.1995 leg. Werner; 1 ô Namibia Aranos 03.02.1995 leg. Werner.

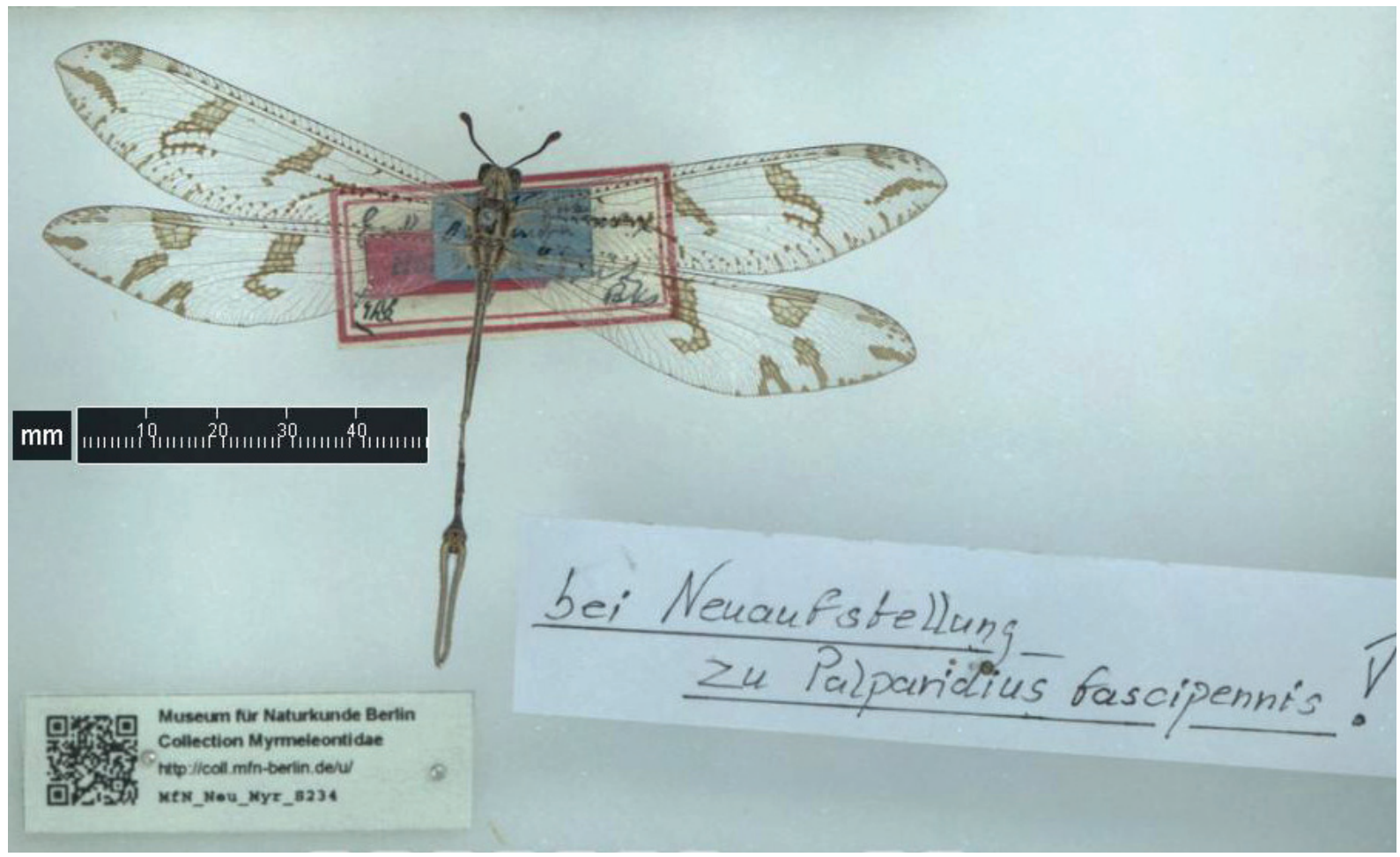

Fig. 5. The type specimen of Echthromyrmex fascipennis Banks, 1911, preserved in ZMHB, Berlin 
Remarks: It is known in Namibia and western part of South Africa (Stange 2004), where it is an endemic species. The type specimen of Palparidius fascipennis (Banks, 1911) (syn. n.) preserved in $\mathrm{ZMBH}$ is a new junior synonym of Palparidius capicola Péringuey, 1910 (Fig. 5).

Palparidius concinnus Péringuey, 1910

Specimens examined: 4 ते 6 q Botswana $60 \mathrm{~km} \mathrm{~N}$ Maun 29.01.1995 leg. Werner; 2 đ Botswana Ghanzi 28.01.1995 leg. Werner.

Remarks: It is also an endemic species in southern Africa. Its distribution in South Africa, Botswana and Namibia was illustrated by Mansell (1979).

Parapalpares solidus (Gerstaecker, 1894)

Specimens examined: 1 त 3 q Iran Salt Lake near Bager Abad 2-4 week of July, 1996 leg. G. Müller.

Remarks: Based on SCMK collection data, it is a common and widespread species from eastern Turkey to Pakistan. It also lives in Oman in the southeastern part of the Arabian Peninsula.

Tribe Ululodini van der Weele, 1909

Ameropterus dissimilis (McLachlan, 1871)

Specimen examined: 1 P Peru Panguana, Rio Yuyapichis, dept. Huanuco 9³7' S 7457' W 27.ix-12.x.2014 leg. L.Börzsöny, in alcohol.

Remarks: Ardila-Camacho et al. (2019) reported specimens from Brasil, Colombia, Peru, Suriname.

Ameropterus peruvianus (van der Weele, 1909)

Specimens examined: 2 q Peru Panguana, biol. Stat. Rio Yuyapichis, Huanucho 220 m 9³7' S 7457' W 27.ix-12.x.2014 leg. L. Börzsöny; 1 đ Peru Panguana, Rio Yuyapichis Dept. Huanucho 220 m 9³7' S 7457' W 23.09-11.10.2011 leg. L. Börzsöny; 2 9 Peru Panguana, Rio Yuyapichis Dept. Huanucho 220 m 9³7' S 7457' W 20.ix-8.x.2012 leg. G. Riedel; ? ? 20.97.10.2013 leg. E. Diller; 1 \& Peru Panguana, Rio Yuyapichis, dept. Huanuco 230 m 9³7' S 7456' W 3-18.x.2009 leg. L.Börzsöny, in alcohol.

Remarks: There are no published faunistic data for the species since the description, only the name can be found in checklists and fauna catalogues (Navás 1912c, Penny 1977, Heckman 2017, Ardila-Camacho et al. 2019). It is known in Peru and Bolivia (van der Weele 1909).

Ameropterus scutellaris (Gerstaecker, 1894)

Specimens examined: 3 o Peru Panguana, Rio Yuyapichis Dept. Huanucho 220 m 9³7' S 7457' W 03-18.10.2009 leg. L. Börzsöny; 1 సै Peru Panguana, Rio Yuyapichis Dept. Huanucho 220 m 9³7' S 7457' W 23.09-11.10.2011 leg. L. Börzsöny.
Remarks: Ardila-Camacho et al. (2019) gave a redescription detailed illustrations and distribution (Bolivia, Colombia, Costa Rica, Honduras, Mexico, Peru) of the species.

Ameropterus selysi (van der Weele, 1909)

Specimens examined: 1 o Peru Panguana, biol. Stat. Rio Yuyapichis, Huanucho 220 m 9³7' S 7457' W 27.ix-12.x.2014 leg. L. Börzsöny; 1 \& Peru Panguana, biol. Stat. Rio Yuyapichis, Huanucho 220 m 9³7' S 7457' W Oct.2010 leg. E. Diller.

Remarks: Redescription and quality illustrations were given by Ardila-Camacho et al. (2019). Its occurrences were documented in Brasil, Colombia, Venezuela. Based on the collection of SCMK, it is a new species for the fauna of Peru and French Guiana.

Cordulecerus elegans van der Weele, 1909

Specimens examined: 14 of 18 q Guyana Georgetown ,..09-10.1997 leg. (NC).

Remarks: First, van der Weele (1909) and later, Penny (1977) as well as Ardila-Camacho et al. (2019) reported specimens from Suriname, Guyana, Brasil and the Dominican Republic. Navás (1924) cited the occurrence of the species from French Guiana. Some species of the genus (Cordulecerus maclachlani Sélys-Longchamps, 1871, Cordulecerus alopecinus (Burmeister, 1839) have been shown to be characterized by an aggregation behavioral pattern (Hogue \& Penny 1988, Covell 1989). Gomes-Filho (2000) reported such a phenomenon as well as this explanation for the fact that this species was collected in larger quantities and sometimes appears to be in large series in the collections.

\section{Cordulecerus inquinatus Gerstaecker, 1888}

Specimens examined: 1 ๙ै Peru Abancay Dept. Apurimac ,..01.1999 leg. NC/(GMU); 1 \& Peru Limony, Distr. Chochamaka $1800 \mathrm{~m}, . .3-4.1999$ leg. NC/(GMU).

Remarks: Ardila-Camacho et al. (2019) listed this species from Costa Rica, Ecuador, Panama, and Peru.

Cordulecerus praecellens (Gerstaecker, 1885)

Specimen examined: 1 \ิ Peru Centro Fuert rio Momon Loreto Dec. 2013, mounted.

Remarks: Ardila-Camacho \& García-García (2012) redescribed the species gave good quality photos of the genitals, recording the occurrences (Ecuador, Panama, Venezuela, Costa Rica, and Colombia) and the habitat of the species. It is a new record for the fauna of Peru. Ululodes sinuatus Banks, 1924 (syn. n.) is a new junior synonym of Cordulecerus praecellens (Gerstaecker, 1885). The type specimen is preserved in MCZC.

\section{Ululodes cajennensis (Fabricius, 1787)}

Specimens examined: 1 F French Guyana Montsinery, Carrefour de Gallion, Emerald Jungle 5-16.12,2003 
leg. M. Kotrba; 2 ð Mexico Chiapas „..v.1990 leg. Lehmann sen.; 1 đ Peru Panguana, Biol. Stat. Rio Yuyapichis, Huanucho 220 m 9³7' S 7457' W 27.ix-12.x.2014 leg. L. Börzsöny; 1 § Peru Panguana, Biol. Stat. Rio Yuyapichis, Huanucho 260m 9³7' S 7457' W Oct.2010 leg. E. Diller; 1 đ ? ? 10-28.v.2013 leg. E. Diller; 1 o Peru Panguana, Rio Yuyapichis Dept. Huanucho 220 m 937' S 7457' W 20.ix-8.x.2012 leg. G. Riedel; 1 ठ Peru Dept Huánaco, Panguana, Rio Yuyapichis 260m 9,37'S 74,56'W 04.2012 leg. E. Diller; 1 đ Peru Dept Huánaco, Bio. Stat. Panguana, Rio Yuyapichis 9,37'S 74,56'W 16-17.04.2003 leg. H.J.u. E.G. Burmeister; 1 ô Peru Panguana, Rio Yuyapichis Dept. Huanucho 220 m 9³7' S 7457' W 20.ix-8.x.2012 leg. G. Riedel; 1 ઈ Venezuela Zulia, Tres Bocas 17.07.1971; 1 q Venezuela Zulia, Rio Catatombo 18.12.1971; 5 đ 2 ㅇ Peru Panguana, Rio Yuyapichis, dept. Huanuco $9^{\circ} 37^{\prime} \mathrm{S} 74^{\circ} 57^{\prime} \mathrm{W}$ 3-18.x.2009 leg. L. Börzsöny in alcohol; 1 q Peru Panguana, Rio Yuyapichis, dept. Huanuco 230 m 9³7' S 7456' W 20.sept.-6.okt.2013 leg. E. Diller, in alcohol.

Remarks: It is a common and widespread species in the tropics of Central and South America from Mexico to Argentina (van der Weele 1909). Ardila-Camacho et al. (2019) published a checklist of the New World spliteyed Ascalaphinae species with their distribution by countries. There are additional unpublished data on the species in the collection of SCMK from Nicaragua and Colombia.

Ululodes macleayanus (Guilding, 1823)

Specimen examined: 1 \% USA Florida Alachua Co. Ganesville S Paynes Praine $20 \mathrm{~m} 29.6093^{\circ} \mathrm{N}$ 82.3042 W 23.06.2010 leg. Hausmann.

Remarks: The North American Ululodes Smith, 1900 species were revised by Shetlar (1977) in his PhD thesis on the basis of the unpublished work Penny et al. (1997) listed the taxonomic status and distribution of species by state. Stange (2000) compiled a website on the owlfly fauna of Florida and based on this the collected specimen was determined. The exact distribution of the species can only be given after a revision of the described Central and South American taxa.

Ululodes venezolensis van der Weele, 1909 stat. $\mathbf{n}$. Specimens examined: 1 P Peru Opto Lima Sta Eulalea (cerio) 1300m 19. 05. 1984 leg. D. Hocking; 1 q Peru Panguana, Rio Yuyapichis Dept. Huanucho 220m 9³7' S 7457' W 20.09-08.10.2012 leg. Diller Malaise Falle; 1 q Peru Lima Chosia 13. 12. 1963 leg. P. Hocking at light; 2 o Peru Opto Loreto Yarinacocha 09. 11. 1964 leg. P. Hocking; 1 đ̊ Peru Hafte Goiladlo 09.06.1996.

Remarks: Further research of the taxon is necessary in order to be able to distinguish morphologically very similar species and subspecies in South America similar to that compiled by Penny et al. (1997) for North American fauna. This taxon was cited by van der Weele (1909) from Venezuela and Colombia. It is a new record for the fauna of Peru.
Tribe Haplogleniini Newman, 1853

\section{Allocormodes junodi van der Weele, 1909} Specimen examined: 1 Tanzania $100 \mathrm{~km}$ N Songea 06.-07.12.1994 leg. Werner, mounted.

Remarks: A complete revision of the genus was performed by Jones (2014) in his PhD dissertation. To determine the species, a key was given and also illustrated the distribution of the species in the tribe. He documented its occurrence from South Africa and Mozambique. It is a new species for the fauna of Tanzania.

\section{Amoea arenosa (Walker, 1853)}

Specimens examined: 1 o Peru Panguana, Rio Yuyapichis Dept. Huanucho 220 m 9 $37^{\prime} S 74^{\circ} 57^{\prime} \mathrm{W}$ 03-18.10.2009 leg. L. Börzsöny, mounted; 2 ㅇ Peru Panguana, biol. Stat. Rio Yuyapichis, Huanucho 220 m 9³7' S 7457' W 27.ix-12.x.2014 leg. L.Börzsöny, mounted; 1 ○े Peru Abancay Dept. Apurimac ,..01.1999 leg. $\mathrm{NC} /(\mathrm{GMU})$, mounted.

Remarks: Jones (2014) figured the distribution data from Brasil, Bolivia, and Argentina. It is a new record for the fauna of Peru.

\section{Amoea impediens (Walker, 1853)}

Specimen examined: 1 ô Peru Divina Montana Resort Pucallpa, Dept. Ucayali 19-21.10.2009 leg. L. Börzsöny.

Remarks: Jones (2014) documented it in Brasil andPeru.

Ascalobyas machadoi Penny, 1982

Specimens examined: $1 \hat{\jmath}$ Peru Dept Huánaco, b. Yuyapichis, Stat. Panguana, 9,37'S 74,56'W 2-18.10.2009 leg. Burmeister; 1 Peru Panguana, biol. Stat. Rio Yuyapichis, Huanucho 220 m 9³7' S 7457' W 12.x.2014 leg. L. Börzsöny; 1 q Peru Panguana, biol. Stat. Rio Yuyapichis, Huanucho 220 m 9³7' S 7457' W Oct.2010 leg. E. Diller; 1 9 Peru Panguana, Rio Yuyapichis Dept. Huanucho 220 m 9³7' S 7457' W 23.09-11.10.2011 leg. L. Börzsöny; 1 q Peru Panguana, Rio Yuyapichis, dept. Huanuco 9³7' S 7457' W 27.ix-12.x.2014 leg. L. Börzsöny in alcohol.

Remarks: Jones (2014) moved it into a new genus (Neascalobyas n. gen. Jones, sl.) and listed occurrences from Equador, Brasil, Peru, and French Guinea.

\section{Ascalobyas microcerus (Rambur, 1842)}

Specimens examined: 2 त Belize Orange Walk District, Rio Bravo Conservation Area, La Milpa Field Station 0-200m 09.05.1997 leg. P.G. Haynes BENHS Expedition; 1 q Belize Orange Walk District, Rio Bravo Conservation Area, La Milpa Field Station 0-200m 8-9.05.1998 leg. P.G. Haynes BENHS Expedition; 2 o Venezuela Zulia, Tres Bocas 24.04.1971; 1 ðै Venezuela Banitas 15.05.1971. 
Remarks: Jones (2014) reported the occurrence in Central America and the northern part of South America (Brasil, Ecuador, Venezuela). It is a new record for the fauna of Belize.

Haploglenius appendiculatus (Fabricius, 1793) Specimen examined: 1 ô USA Wewahitchka, Florida 01.07.1995 leg. H. Lehmann.

Remarks: The genus was revised by Jones (2014). Originally, Rambur (1842) moved it into the genus of Haploglenius Burmeister, 1839 then the species name with the current combination was reinstated as valid by Jones (2014). It is a common species in the southeastern part of the USA.

Haploglenius brunneus Jones, sl.

Specimens examined: 1 q Peru Panguana, biol. Stat. Rio Yuyapichis, Huanucho 220 m 9³7' S 7457' W 27.ix-12.x.2014 leg. L. Börzsöny; 1 P Peru Panguana, Rio Yuyapichis Dept. Huanucho 220 m 9³7' S 7457' W 23.09-11.10.2011 leg. L . Börzsöny; 1 ^ Peru Rodriguez de Mendoza, Dept. Amazonas 5.1.1997 leg. Rautenstrauch; 1 o Peru Rodriguez de Mendoza, Dept. Amazonas 1.ii.1998 leg. Rautenstrauch.

Remarks: Jones (2014) indicated occurrences from South Mexico to Bolivia.

Haploglenius costatus (Burmeister, 1839)

Specimens examined: 3 o Peru Chancamoyo ,..xii.1962 leg. NC/GMU; 1 q Peru Manu Park, Madre de Dios 700 m 20.02.1998 leg. NC/Lehm. 1 Brasil Corupa ,..,..1996 leg. (NC).

Remarks: Penny (1981) documented the species in Peru and Jones (2014) mentioned it from Brasil, Bolivia, Colombia, and Panama.

Haploglenius cuboides Jones, sl.

Specimens examined: 1 \ Peru Abancay Dept. Apu-

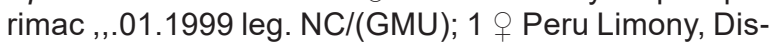
tr. Chochamaka $1800 \mathrm{~m}, .3-4.1999$ leg. NC/(GMU); 1 \& Peru Manu Park, Madre de Dios 500-800 m ,..,.,1998 leg. (NC); 1 o Peru Panguana, biol. Stat. Rio Yuyapichis, Huanucho 220 m 9³7' S 7457' W 27.ix12.x.2014 leg. L. Börzsöny; 1 † Peru Biol Stat. Panguana Rio Yuyapichis, Huanuco 220m 9,37'S 74,57'W 10.2010 leg. E. Diller.

Remarks: Jones (2014) described this species from Brasil, it is a new record for the fauna of Peru.

Haploglenius luteus (Walker, 1853)

Specimens examined: 1 Peru Limony, Distr. Chochamaka $1800 \mathrm{~m}, . .3-4.1999$ leg. NC/(GMU); 1 o Peru Rodriguez de Mendoza, Dept. Amazonas 12.x.1997 leg. Rautenstrauch.
Remarks: Based on a distribution map edited by Jones (2014), it occurs in the Amazon basin (Brasil) but was also detected in Peru.

Haploglenius normani Jones, sl.

Specimens examined: 1 đo Peru MD.Boca Rio De La Torre 22.10.1985 leg. G. Lamas; 1 क Peru MD, 15km E Puerto Maldanado 200m 04.11.1988 leg. G. Lamas.

Remarks: Jones (2014) described this species from Brasil, Bolivia, Peru, and North Argentina.

Haploglenius peruvianus van der Weele, 1909 Specimens examined: 3 o 1 Peru Manu Park, Madre de Dios 700 m 20.02.1998 leg. NC/Lehm.; 1 ઈ Peru Panguana, Rio Yuyapichis Dept. Huanucho 220 m 9³7' S 7457' W 03-18.10.2009 leg. L. Börzsöny; 1 đ. Peru Amazonas, Quebrada, Putoiman, Rio Maranón 04 311m 22'24,85"S 77 56'4.22"W 26-27.08.2010 leg. W. Paredes; 1 \ Peru MD.Boca Rio De La Torre 300m 18.10.1985 leg. G. Lamas; 1 ^ Peru AM Cordirella del Cóndor PV 22 („Falsa Paquisha”) 800m 30.10.1987 leg. G. Lamas; 1 q Peru Cana Brava 21.10.1980.

Remarks: Jones (2014) documented its occurrences in Brasil, Bolivia, Equador, and Peru.

Protidricerus elwesii (McLachlan, 1891)

Specimens examined: 2 Burma Dawna 25.05.1996 leg. H. Lehmann; 1 q Burma Dawna 27.05.1996 leg. H. Lehmann; 2 o 5 q Burma Dawna 10.4.1997 leg. H. Lehmann; 1 q Burma Dawna --.05.1998 leg. H. Lehmann; 1 q Burma Tenasserim 10.4.1997 leg. $\mathrm{H}$. Lehmann; 1 Thailand Corat 27.06.1996 leg. H. Lehmann; 1 ㅅ 1 \% Thailand Chiang Rai --.05.1997 leg. ? (NC).

Remarks: It is a widespread species in Asia from Pakistan (Sziráki 2000, Hassan et al. 2019) via India (Ghosh 1988, 2000) and China (Wang et al. 2018) to Taiwan (Stange \& Wang 1997, Ábrahám 2008). It is a new species for the local fauna of Myanmar, Thailand, and Vietnam based on the collection of SCMK.

Tmesibasis rothschildi van der Weele, 1907

Specimens examined: 1 o N Kenya Sidiot 1819.11.1995 leg. Werner, mounted; 1 Kenya Voi, Sagala Reg. 12.1994 leg. Werner, mounted.

Remarks: Jones (2014) revised the genus and documented the occurrence in Somalia and Kenya. It is a new record for the fauna of Ethiopia based on the collection of SCMK.

Tribe Ascalaphini Lefèbvre, 1842

Acheron longus (Walker, 1853)

Specimens examined: 2 1 q China Heinan Dao, He Ling 800-1500m --.5-6.2000 leg. NC/GMU; 1 ते China Guang Dong Province Nan Long Mts 600-1200m 
--.5-6.2000 leg. NC/GMU; 1 \& China Fuijan prov. mid6.1999 leg. NC/GMU; 1 क Cambodia Patin 10.06.1999 leg. NC/Lehm.; 1 o Thailand Corat 26.06.1996 leg. H. Lehmann; 1 q 26.05.1997 leg. H. Lehmann; 1 ㅇ 07.05.1996 leg. H. Lehmann; 3 ठ 1 India U. Pradesh, Rishikes 450 m 07.1991 leg. Werner.

Remarks: Tauber et al. (2019) suggested that $A$. longus (Walker, 1853) had priority over the name of $A$. trux (Walker, 1853). The basic colour of the wings depends on the age of the specimens, from the fully transparent wing to the reddish-brown colour, there are many colour variations among specimens. It is a widespread and common species in the area of Oriental region from India to Malaysia. Moreover, it also occurs in the eastern part of the Palearctic (China, Japan) (Ábrahám 2008).

Afroasca buyssoni (van der Weele, 1909) (Fig. 6) Specimens examined: 1 o Kenya Sagala Reg. near Voi 11.1994 leg. Werner; 2 đ Sidiot 18-19.11.1995 leg. Werner, mounted.
Remarks: Suphalacsa abdominalis McLachlan, 1871 was described by McLachlan (1871) on the basis of two type specimens, however, they belong to two different taxa. The species description is based on a male specimen preserved in BMNH, London and collected in Gabon (McLachlan 1871). Tjeder (1992) mentioned it as an undescribed generotype species: "N. gen. 4, Type species: Suhpalacsa abdominalis McLachlan, 1871". In his monograph and the revised collections (e.g. MRAC, Tervuren) he referred to an undescribed genus as "Imparomitus abdominalis". Until now, this genus is nomen dubius (Ábrahám 2017b).

McLachlan (1871) notes on the second type specimen of the species: „A second example in the Oxford $\mathrm{Mu}$ seum [OXUM], perhaps a female, differs in the wings being much clouded all over with smoky brown. The underside of the thorax and base of the abdomen is of a pale salmon-colour."

Tauber et al. (2019) found the second type specimen of Suhpalacsa abdominalis McLachlan, 1871 in the collection of OXUM, which was conspecific with a male Suphalomitus buyssoni van der Weele, 1909. Ábrahám (2017b) recently described a new genus, Afroasca

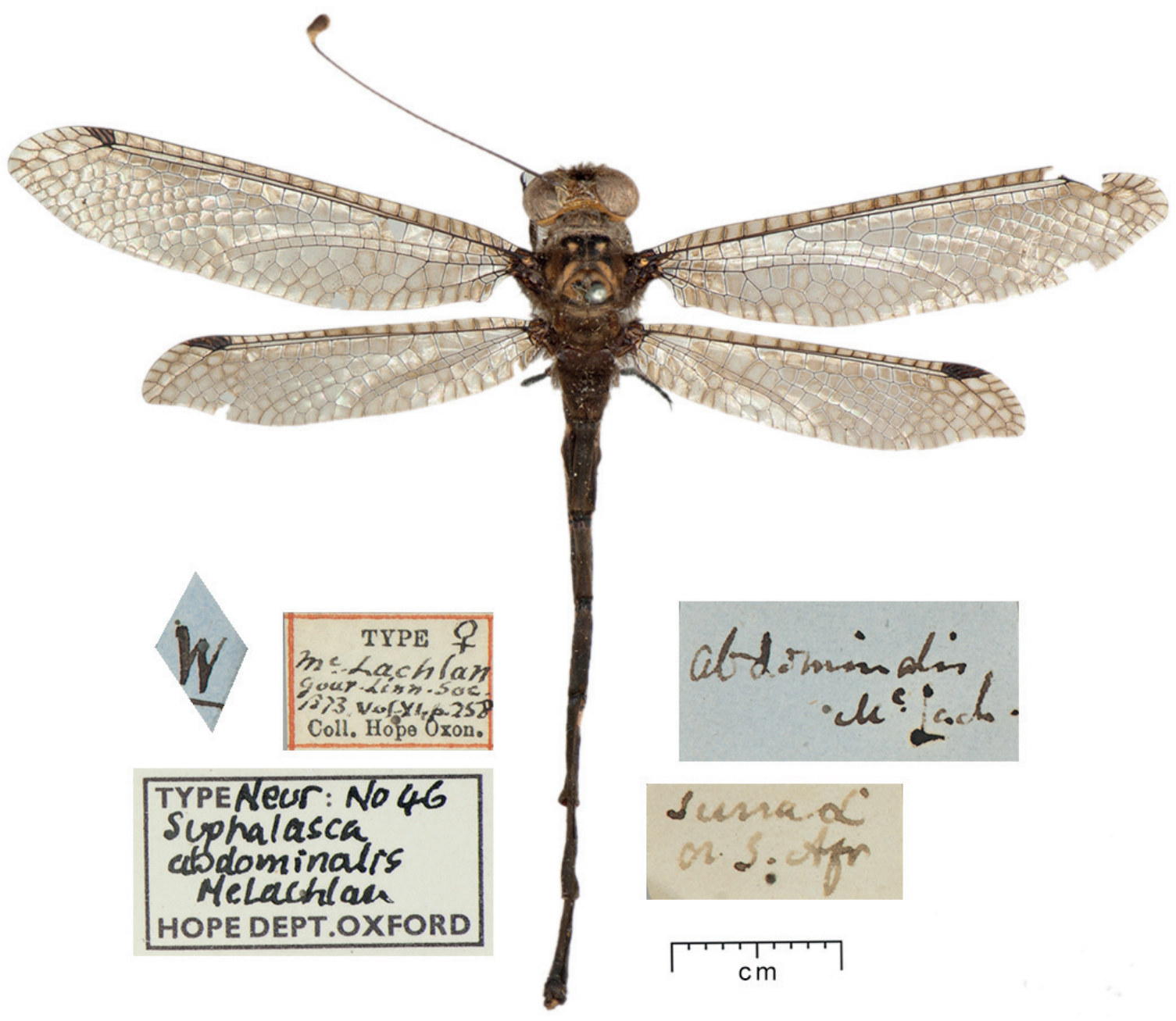

Fig. 6. Type of Suhpalacsa abdominalis McLachlan, 1871, preserved in OXUM, Oxford. Type is a male specimen! 


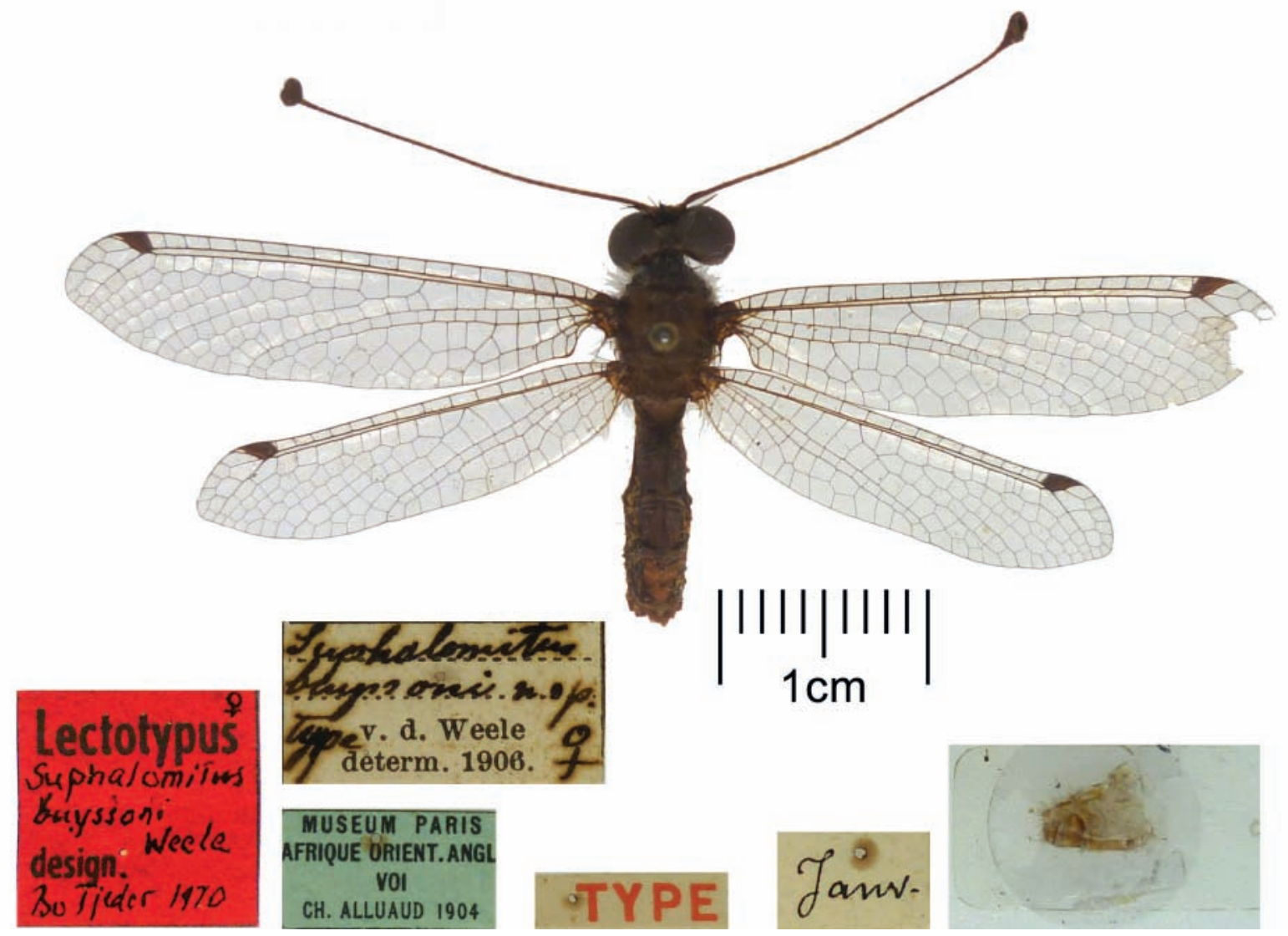

Fig. 7. Lectotype female of Suphalomitus buyssoni van der Weele, 1909, preserved in MNHN, Paris

Ábrahám, 2017 and designated Suphalomitus buyssoni van der Weele, 1909 as a generotype species. van der Weele (1909) also examined a female specimen (Fig. 7) when describing the species, which was preserved in the collection of MNHN, Paris. Later, this female specimen was designated by Tjeder as a lectotype but the designation was not published yet (present designation).

Occurrences of the species was mentioned by Navás (1914: Kenya, 1928: Tanzania) and Whittingthon (2001: Mozambique). The entomological collection of SCMK contains faunistic data from several African countries: RSA, Namibia, Zambia, Tanzania, Kenya, Ethiopia, Gabon. Based on the collection data, it is in flying in southern Africa (RSA, Namibia, Zambia) between November and January, in the Eastern and Western Africa (Tanzania, Kenya, Ethiopia, Gabon) between November and May.

Afroasca doboszi Ábrahám, 2017

Specimens examined: 1 ô Kenya Sagala Reg. near Voi 11.1994. leg. Werner, mounted; 1 T Kenya Malindi, Mangoplantage, Sümpf Kissvany Complex 07.04.1989 Leg: U. Kupka, mounted.

Remarks: So far, only the male holotype specimen was known. It is the second and third documented speci- mens which also come from Kenya (Ábrahám 2017b). The species appears to have an overlap area with the previous species. The female of the species is still unknown (Ábrahám 2017b).

\section{Agrionosoma dohrni van der Weele, 1909}

Specimens examined: 1 + Burma [Mianmar] Dawna 25.05.1996 leg. H. Lehmann; 2 ㅇ 10.04.1997 leg. H. Lehmann; 1 \& Burma [Mianmar] Tenasserim 06.05.1995 leg. H. Lehmann; 1 đ̂ 1 28.04.1996 leg. H. Lehmann; 3 o 16.04.1996 leg. H. Lehmann; 2 ㅇ 17.04.1996 leg. H. Lehmann.

Remarks: Since the description, only Ghosh (1988) and Whittingthon (2002) mentioned its occurrence in India (Sikkim, West Bengal). Otherwise, it was only documented in various checklists (Ghosh \& Sen 1977, Sziráki 1998) or in monographs (Navás 1912c, Ghosh 2000). These publications merely repeated previous literature data from India. The type specimen is preserved in MIZ (Fig. 8). Agrionosoma pendleburyi Fraser, 1927 (syn. n.) is a new junior synonym of Agrionosoma dohrni van der Weele, 1909. The type is preserved in $\mathrm{BMNH}$, London (Fig. 9). It is an extremely rare species and a new record for the fauna of Myanmar. 


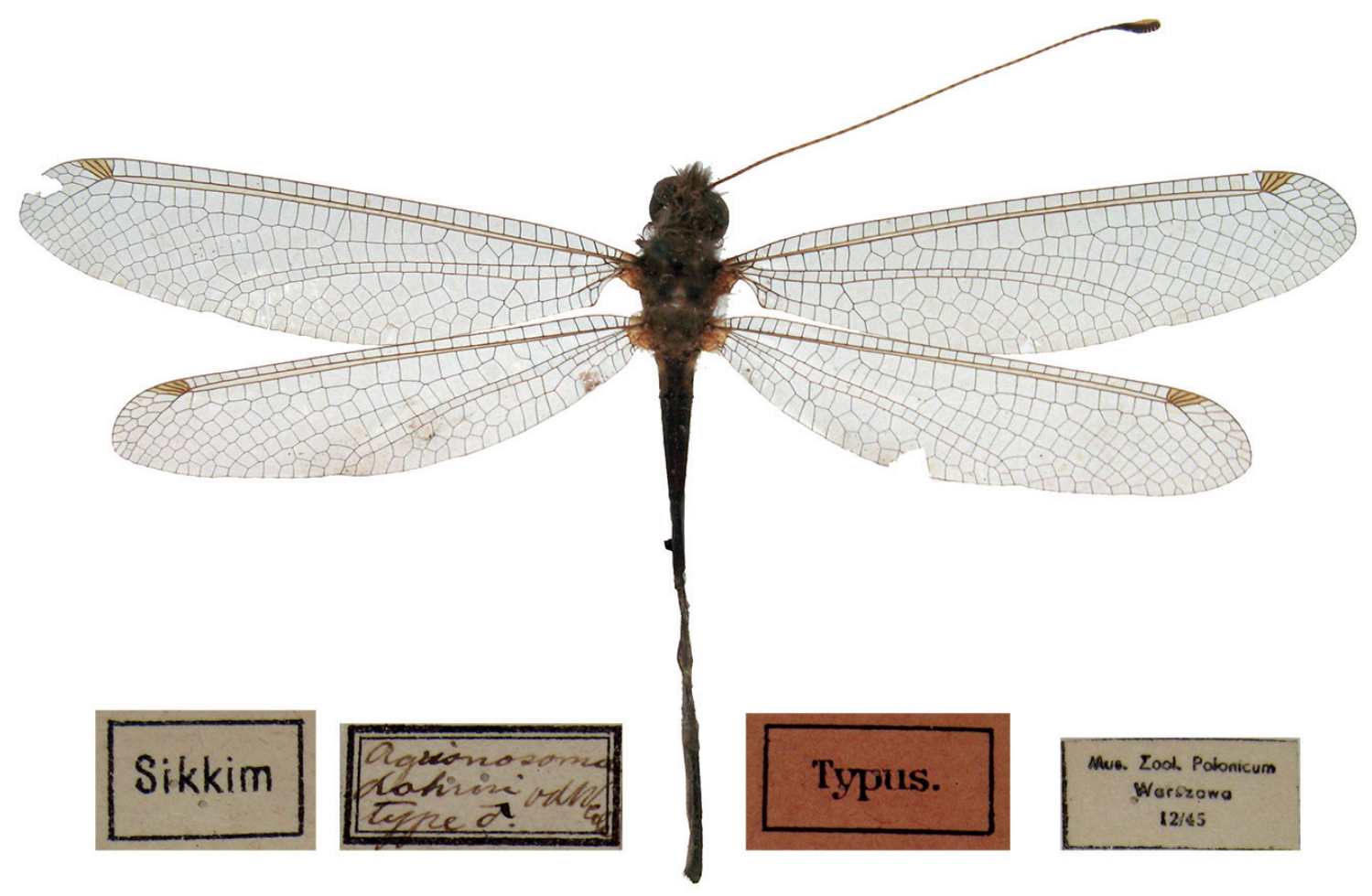

Fig. 8. The type specimen of Agrionosoma dohrni van der Weele, 1909, preserved in MIZ, Warsawa

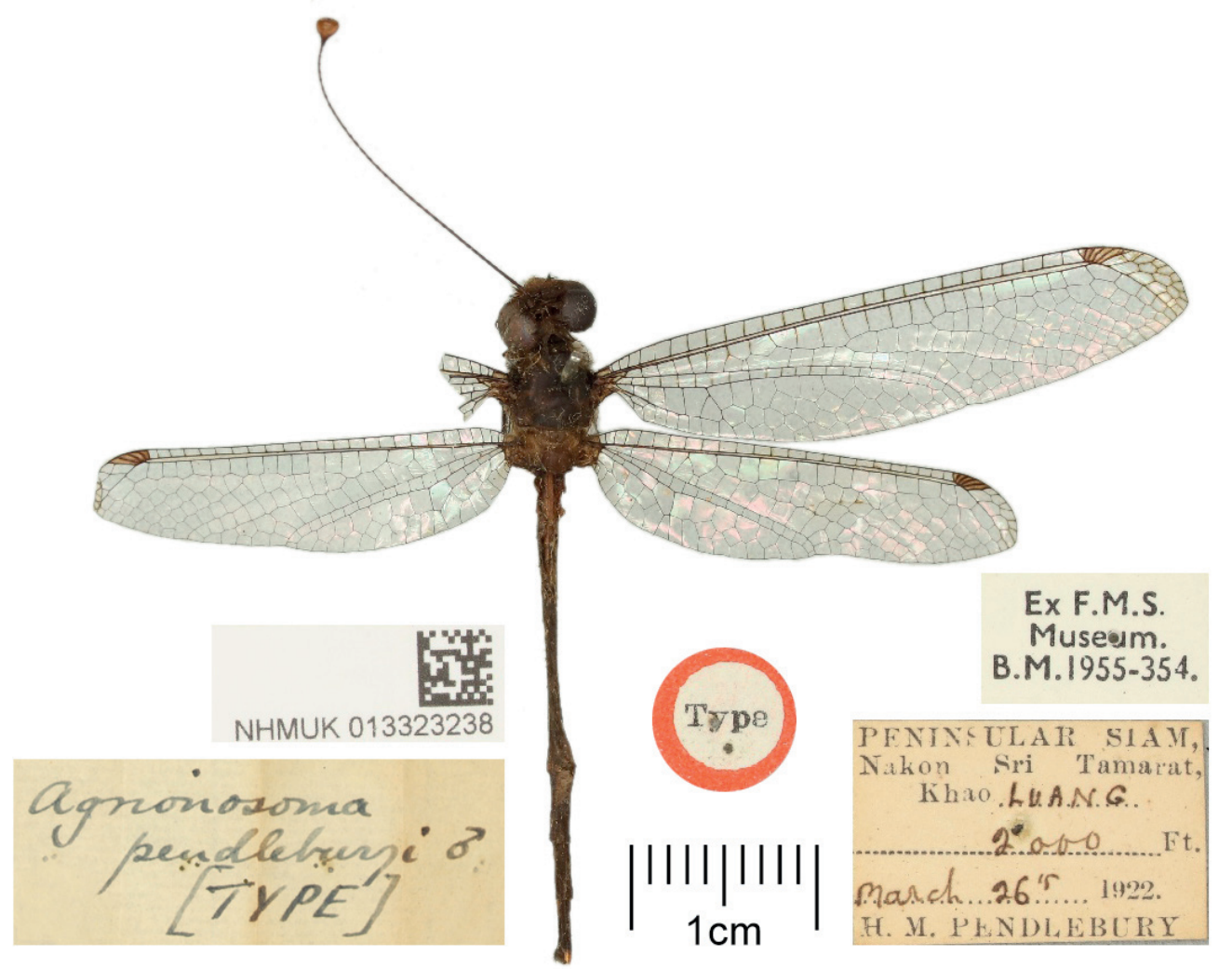

Fig. 9. The type specimen of Agrionosoma pendleburyi Fraser, 1927 (syn. n.) preserved in BMNH, London is a new junior synonym of Agrionosoma dohrni van der Weele, 1909 


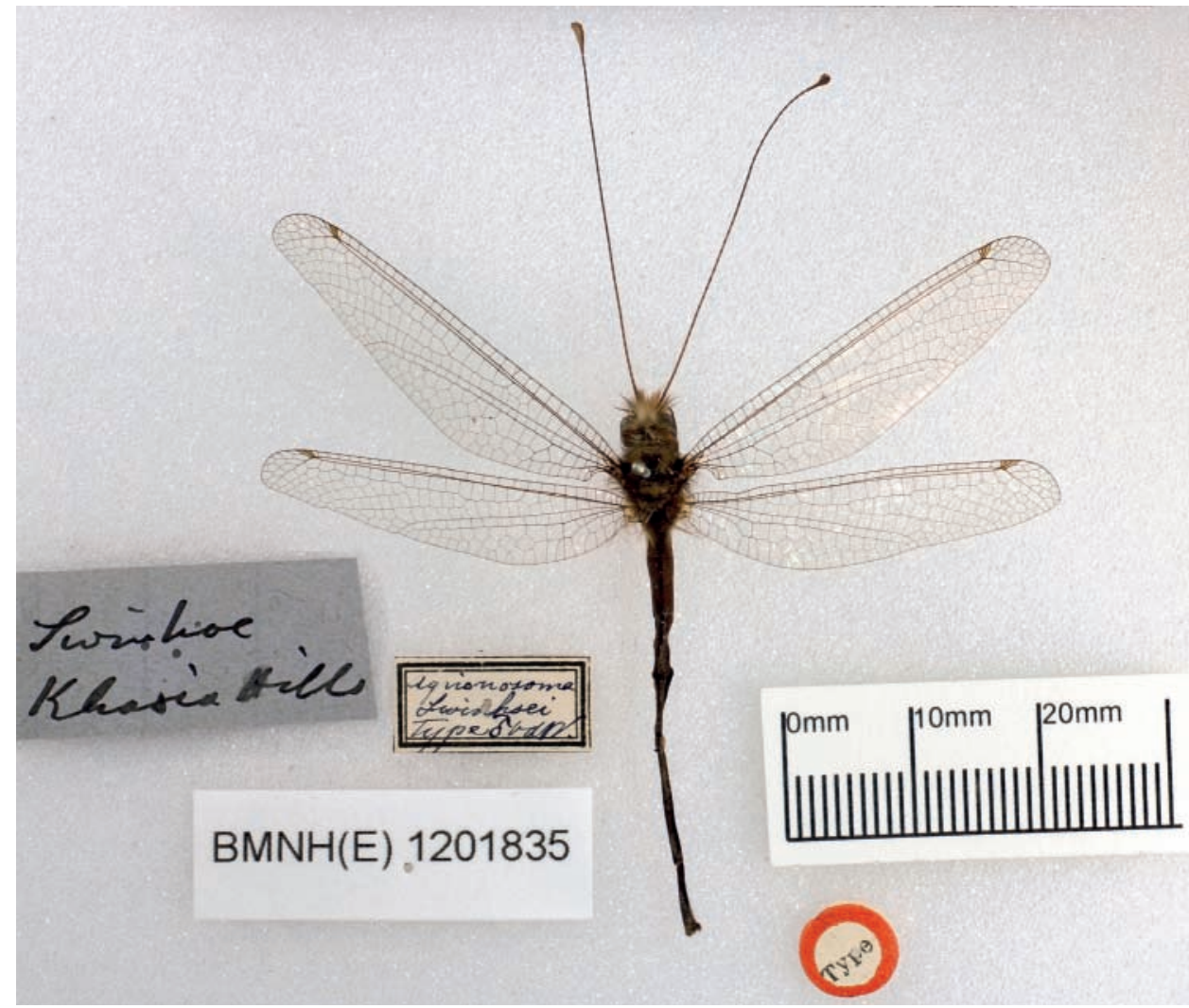

Fig. 10. The type specimen of Agrionosoma swinhoei van der Weele, 1909, preserved in $\mathrm{BMNH}$, London

Agrionosoma swinhoei van der Weele, 1909 Specimen examined: 1 q Burma [Myanmar] Dawna 10.4.1997 leg. H. Lehmann.

Remarks: As with the previous species, it has no distribution data since the species description, only an Indian locality in Punji (Madhja Pradesh) published by Whittingthon (2002). The specimen was compared to the type preserved in the BMNH, London (Fig. 10).

The type locality in India, Assam: Khasia Hills (van der Weele, 1909) is the same as Meghalaya: Khasi Hills published by Ghosh (2000) since the Khasi Hills, and the entire Meghalaya state was administratively part of Assam before 1970. In older sources, in particular, the alternative transcription Khasia Hills is seen. It is the first record for the fauna of Myanmar.

Ascalaphus festivus (Rambur, 1842)

Specimens examined: 2 1 Kenya Voi, Sagala Reg. 12.1994 leg. Werner, mounted; 1 o Tanzania Babati, $30 \mathrm{~km}$ to Dodoma 02.-03.12.1994 leg. Werner.

Remarks: It is widespread in Africa (Prost 2013) but was also found in West Asia (Aspöck et al. 2001, Monerrat \& Ábrahám 2020) and in Europe on the island of Sardinia (Italy) (Pantaleoni et al. 2013).

Ascalohybris angulata (Westwood, 1847)

Specimens examined: 2 I India Periyar, Kumili, TN 23-26.10.1997 leg. Werner
Remarks: Walker (1853), McLachlan (1873), van der Weele (1909), Needham (1909), Navás (1912c), Whittingthon (2002), etc. were mentioned collecting sites only in India. Fraser's (1927) data from Singapore seems to be uncertain and needs confirmation.

\section{Ascalohybris subjacens (Walker, 1853)}

Specimens examined: 1 \% China South Hubei, border to Hunan 1200-1600m --.08.1999 leg. NC/GMU; 1 ઈิ 5 우 China Wuzhi Shan, Heinan Dao 800-1800m --.6-7.2000 leg. NC/GMU; 1 \& China Guang Dong Province Nan Long Mts 600-1200m --.5-6.2000 leg. NC/GMU; 1 ð China Haikou, Heinan Dao 0-100m --.04.2000 leg. NC/GMU; 3 ô 1 q Burma Tenasserim 28.04.1996 leg. H. Lehmann; 1 ㅇ Burma Tenasserim 07.05.1996 leg. H. Lehmann.

Remarks: It is a widespread species in East Asia: North Korea, Japan, China, Taiwan, Laos, Thailand, and Vietnam based on the entomological collection of SCMK.

\section{Disparomitus simplex Kimmins, 1950}

Specimens examined: 1 \ 1 Kenya Sagala Reg. near Voi 11.1994 leg. Werner, mounted.

Remarks: Michel (2019) recently performed a revision of the African genus Disparomitus van der Weele, 1909. He cited the species only from Kenya (type locality) and Ethiopia. 
Disparomitus transvaliensis (van der Weele, 1909) Specimens examined: 1 đ Kenya Voi, Sagala Reg. 12.1994 leg. Werner mounted; 1 đ Tanzania 100 km N Songea 06.-07.12.1994 leg. Werner, mounted; 1 ㅇ , near Same $30 \mathrm{~km}$ to Dodoma 11.12.1994 leg. Werner, mounted.

Remarks: A revision of the genus Disparomitus van der Weele, 1909 (Michel 2019) revealed their faunistic data come from South Africa to Sudan in South and East Africa. The entomological collection of SCMK also includes new data to the fauna of Ethiopia, Cameroon, and Namibia.

\section{Dorsomitus sp. 1}

Specimen examined: 1 Tanzania 30km W Songea 8.12.1994 leg. Werner, mounted.

Remarks: Only the male of the two described species of the genus can be surely distinguished (Michel \& Mansell 2018) because the range of the two species overlaps and no distinctive morphological features have yet been found between females for accurate determination.

\section{Encyoposis seydeli (Navás, 1929)}

Specimens examined: 2 Tanzania $100 \mathrm{~km}$ N Songea 06.-07.12.1994 leg. Werner, mounted; 1 o Tanzania 50km N Songea, Ruvuna Prov. 12.1994 leg. Werner, mounted.

Remarks: There is a few data in the literature (Navás 1931, Esben-Petersen 1936) from tropical Africa. The entomological collection of SCMK includes one specimen from Tanzania and another from Zambia. The latter one is a new record for the fauna of Zambia. It is on the wing from November to December.
Glyptobasis cornuta Kimmins, 1949

Specimen examined: $1 \hat{\jmath}$ India U. Paradesh, Rishikes 450 m 07.1991 leg. Werner, mounted.

Remarks: Besides the locality of the type specimen, Ghosh (1988) reported additional faunistic data from India (Orissa). Otherwise, it was found only in checklists (Ghosh \& Sen 1977, Sziráki 1998). Based on the entomological collection of SCMK, it is a new species for the fauna of Nepal.

Helicomitus placidus (Gerstaecker, 1894)

Specimen examined: 1 q Thailand Corat 27.06.1996 leg. H. Lehmann.

Remarks: The taxonomic status of the species was clarified by Kimmins (1949). It is a relatively widespread and common species in Southeast Asia (Ábrahám 2016).

Helicomitus procax (Walker, 1853)

Specimen examined: $1 \hat{\jmath}$ India U. Paradesh, Rishikes 450 m 07.1991 leg. Werner, mounted.

Remarks: Revision of Helicomitus species was given by Kimmins (1949) based on the shape of the anal area of the forewing and the processus and special hair tufts on the mesothorax to distinguish morphologically very similar species. Kimmins (1949) was uncertain about the validity of the species during the revision of the genus because of his type specimen from Nepal was a female. The male Helicomitus procax can be easily distinguished from other Helicomitus species by the shape of processus of the mesothorax, which is longer than it is wide (Fig. 11). After the description, it was mentioned only in the Asian ascalaphid checklist (Sziráki 1998).

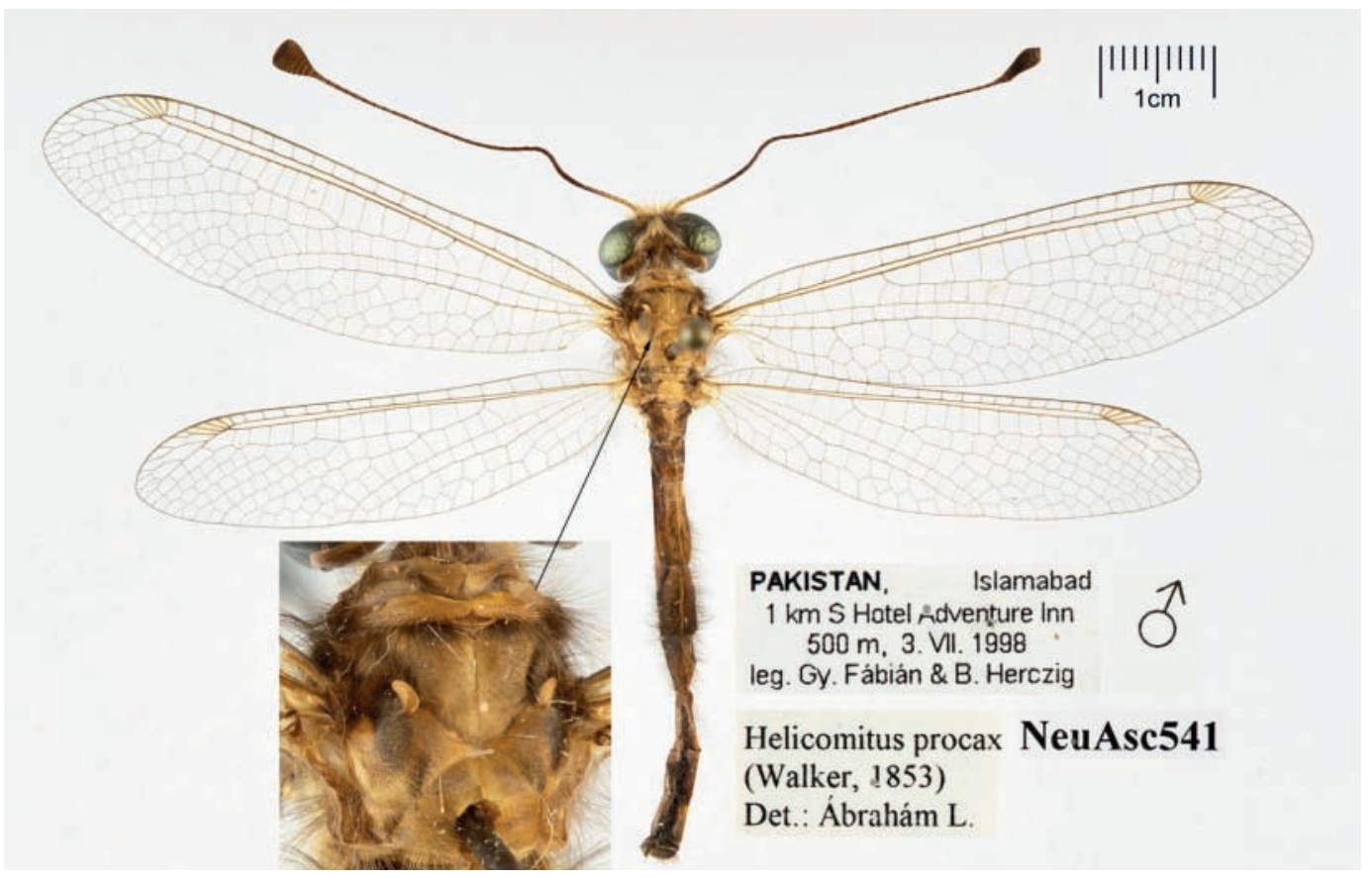

Fig. 11. Habitus and magnifield male thorax of Helicomitus procax (Walker, 1853) in dorsal view, preserved in SCMK, Kaposvár 
It is a new species for Indian fauna (Chandra \& Sharma ????). Further specimens can also be found from Pakistan in the entomological collection of SCMK.

Libelloides lacteus (Brullé, 1832)

Specimens examined: 5 q Greece Small Prespa Lake 10.08.1996 leg. L. Börzsöny.

Remarks: In Europe, the species is widespread in the Mediterranean from southern France to Greece and is common in several places (Aspöck et al. 2001). Recently, Dobosz \& Ábrahám (2007) published the Turkish distribution map of the species.

Libelloides macaronius (Scopoli, 1763)

Specimens examined: 2 of 7 Iran Central Elbros Naver ca. $3000 \mathrm{~m}$ leg. G. Müller; $3 \delta$ Greece Small Prespa Lake 10.08.1996 leg. L. Börzsöny.

Remarks: It is a widespread species from Central Europe (Aspöck et al. 2001) to Central Asia (Wang et al. 2018: China, Xinjiang).

Libelloides sibiricus (Eversmann, 1850)

Specimen examined: 1 China Shanxi Province Taigu ca $112^{\circ} 30^{\prime} \mathrm{W} 37^{\circ} 25^{\prime} \mathrm{N}--.05 .1995$ leg. ? (GMU).

Remarks: Known occurrence in Korea, China, and Russia. It is a new record for the Mongolian fauna based on the entomological collection of SCMK.

Maezous tomijankae Ábrahám, 2008

Specimen examined: 1 đC China Guang Dong Province Nan Long Mts 600-1200m --.5-6.2000 leg. NC/GMU.

Remarks: It is a rare species in SE Asia, type specimens are from Laos and its new records are known not only in China but also in Vietnam based on the entomological collection of SCMK.

Maezous umbrosus (Esben-Petersen, 1913)

Specimens examined: 9 q China Hunan Province --.0607.1999 leg. NC/GMU; 1 China South Hubei, border to Hunan 1200-1600m --.08.1999 leg. NC/GMU.

Remarks: Earlier, it was known only in the fauna of Taiwan (Esben-Petersen 1913), later was documented as a widespread species in southeastern continental Asia (Ábrahám 2008, Wang et al. 2018). There are many localities in China: Guangxi, Hubei, Shaanxi, Guizhou, Hunan, Henan, Yunnan, Jiangxi (Wang et al. 2018). Based on SCMK collection data, it was collected in Taiwan, SE China, Vietnam, and Thailand.

Malesianus harisi (Ábrahám, 2008)

Specimen examined: 1 I Indonesia Sumatra, Sibolangit --.03.1997 leg. ? (NC).

Remarks: Known in Malaysia and the Philippines (Ábrahám 2016). New record for the fauna of Indonesia.
Nephoneura costalis van der Weele, 1909

Specimen examined: 1 Ethiopia Gemu Gofa Prov. Near Arba Minch 04.1994 leg. Werner, mounted.

Remarks: It was reported from Togo, Tanzania (van der Weele, 1909) Zimbabwe (Whittington 2002), Zaire (Esben-Petersen 1936). Unpublished faunistic data from Zambia, Ghana, and Cameroon can be found in the entomological collection of SCMK.

Phalascusa vassei van der Weele, 1909

Specimen examined: 1 o Kenya Taita region near Voi leg. Werner, mounted.

Remarks: The area of this species extends from south of the Equator but does not reach South Africa. Known from Mozambique (van der Weele 1909), Zaire (Navás 1912c, Banks 1920) and other countries: Kenya, Zambia, and Namibia, from where the species is new to the local fauna based on the collection of SCMK.

Protacheron philippinensis (van der Weele, 1904) Specimen examined: 1 त Thailand Corat 14.5.1996 leg. H. Lehmann.

Remarks: The type specimen is from the Philippines. Subrecently, it was documented in Taiwan (Sziráki 2000) and China: Guihzu, Guangxi Yunnan, Hainan (Wang et al. 2018). More faunistic data are available from several SE Asian countries: Thailand, Laos, and the Philippines in the collection of SCMK.

Suphalomitus formosanus Esben-Petersen, 1913 Specimen examined: 1 c China South Hubei, border to Hunan 1200-1600m --.08.1999 leg. NC/GMU.

Remarks: It was previously considered to be an endemic species (Banks 1937, Stange \& Wang 1997, Sziráki 1998, Ábrahám 2008) in Taiwan, but it was also recorded in China: Guizhou, Guangxi, Hainan (Wang et al. 2018). There are a dozen specimens also from Vietnam in the collection of SCMK

\section{Suphalomitus lutemaculatus Yang, 1992}

Specimen examined: 1 C China Guang Dong Province Nan Long Mts 600-1200m --.5-6.2000 leg. NC/GMU;

Remarks: So far, it has been found only in China: Henan, Zhejiang, Fujian (Wang et al. 2018). Previously, I incorrectly synonymized it based on a discoloured female (Ábrahám 2008) but it is a valid species. Wings of male specimens are significantly smaller in size than that of females and are recognizable by a yellow spot in front of the forewing on the lateral side of the mesonotum.

Suhpalacsa donckieri Navás, 1913

Specimens examined: 3 \% Thailand Chiang Rai --.05.1997 leg. ? (NC), mounted. 


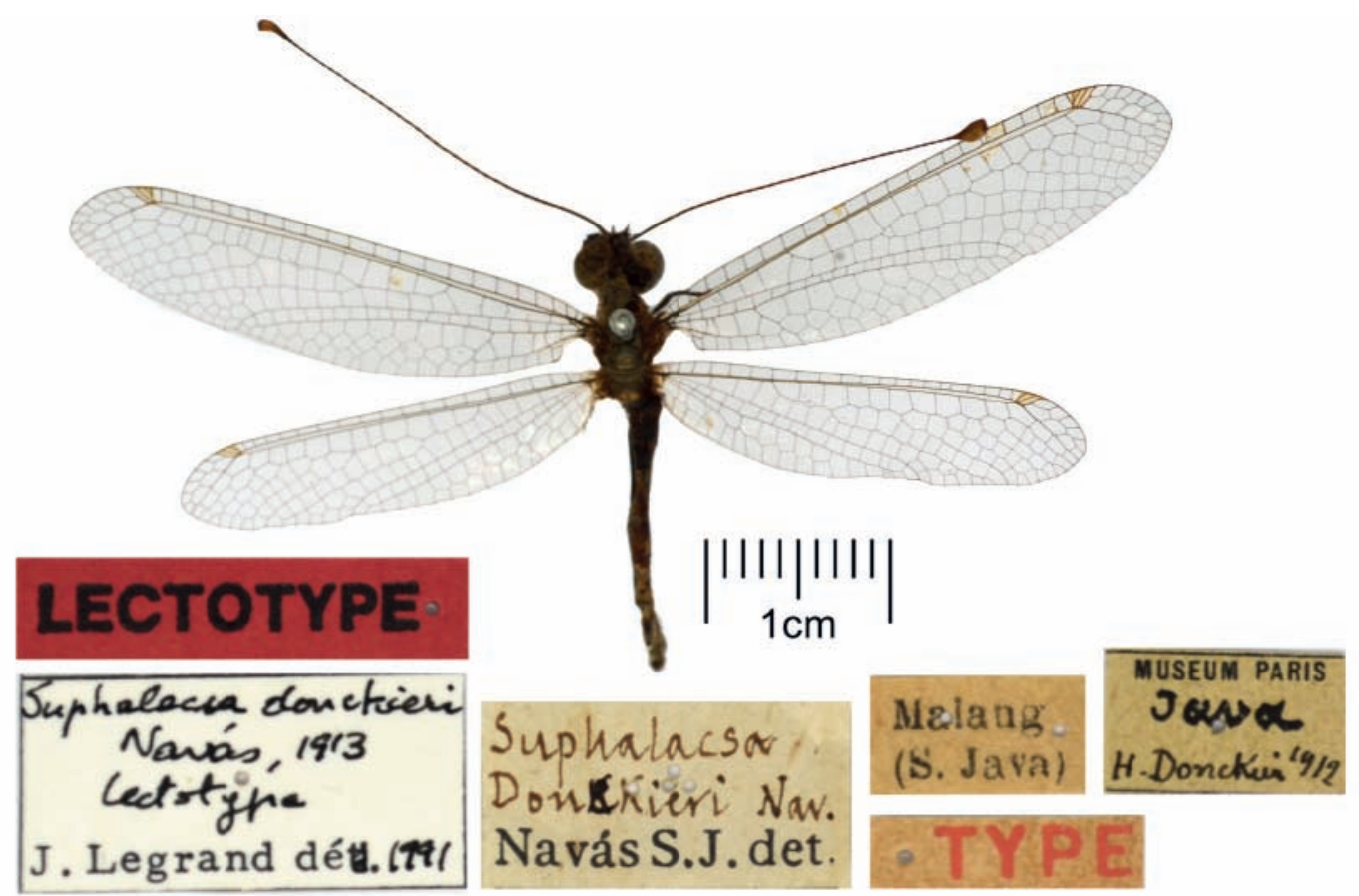

Fig. 12. Lectotype specimen of Suhpalacsa donckieri Navás, 1913, preserved MNHN, Paris

Remarks: Suhpalacsa Lefèbvre, 1842 species described from Southeast Asia needs species and generic-level revision. I compared the specimens found in the Börzsöny collection with the type specimen preserved in MNHN (Paris) (Fig. 12). The lectotype was designated by Legrand in 1991 but the designation has not been published yet (present designation). The description of the type specimen is based on an immature individual. The collection of SCMK includes specimens from Cambodia, Laos, Thailand, and Vietnam. Suhpalacsa reductus Banks, 1931 described from the Philippines is morphologically very close to Suhpalacsa donckieri Navás, 1913.
Tytomyia nigrifrons Tjeder \& Hansson, 1992 Specimens examined: 3 \& Namibia Hardap Dam 31.10.1994 leg. Werner, mounted.

Remarks: Endemic species in Namibia (Tjeder \& Hansson 1992).

\section{Acknowledgements}

The author is grateful to Lászlóné Börzsöny for donating her husband's collection, books and collecting equipment to the natural history collection of the Rippl-Rónai Museum, Kaposvár in 2019. Further thanks go to the curators who made it possible to examine the type specimens or provided the author with high-quality digital photos. 


\section{References}

Abdalla, I. H.; Mansell, M. W.; Sole, C. L. 2019: Revision of the southern African genera Nemopterella Banks and Nemia Navás (Neuroptera: Nemopteridae: Nemopterinae), with descriptions of new genera and species. - Zootaxa 4635: 1-89.

ARdila CAmacho, A.; Garcia García, A. 2012: Nuevos registros y redescripción de dos especies del género Cordulecerus Rambur 1842 (Neuroptera: Ascalaphidae) de Colombia. - Boletín de la Sociedad Entomológica Aragonesa 50: 505-511.

Ardila-Camacho, Adrian, Jorge A. Noriega \& Fernando AcevedoRAMOS. 2019: New genera records of split-eyed owlflies (Neuroptera: Myrmeleontidae: Ascalaphinae) from Colombia. - Papéis avulsos de zoologia 59: e20195951, p. 1-18.

Aspöck, H.; Aspöck, U.; Hölzel, H.[; Rausch, H.] 1980: Die Neuropteren Europas. 2 vols. Goecke and Evers, Krefeld, West Germany. v. 1: 495 pp.; v.2: 355 pp.

Aspöck, H., HöLzEL, H. \& AsPöcK, U. 2001: Kommentierter Katalog der Neuropterida (Insecta: Raphidioptera, Megaloptera, Neuroptera) der Westpaläarktis. - Denisia 2: 1-606.

ÁBRAHÁM, L. 2008: Ascalaphid studies VII. On the ascalaphid fauna of Taiwan (Neuroptera: Ascalaphidae). - Natura Somogyiensis 12: 63-77.

ÁBRAHÁM, L. 2012. „On the other hand, what is this Eastern aeschnoides?" (Morton 1926) - an undescribed Palpares species from the Eastern Mediterranean (Neuroptera: Myrmeleontidae). Natura Somogyiensis 22: $65-102$

ÁвRAHÁm L. 2016: Ascalaphid studies X. Maezous maezousi sp. n. - a new ascalaphid species from the Philippines (Neuroptera: Ascalaphidae). - Natura Somogyiensis 28: 51-64.

ÁBRAHÁM L. 2017a: New data to the Moroccan Myrmeleontiformia (Nemopteridae, Myrmeleontidae, Ascalaphidae) fauna. - Natura Somogyiensis 30: 75-138.

ÁBRAHÁM, L. 2017b: Ascalaphid studies XI. A new owlfly (Neuroptera: Ascalaphidae) from Kenya: Afroasca doboszi gen. and sp. nov. Annals of the Upper Silesian Museum in Bytom Entomology 36: (online 001): 1-6.

ÁBRAHÁM, L. 2014: Contribution to the knowledge of the genus Halter (Neuroptera: Nemopteridae). - Natura Somogyiensis 25: 167-188.

BANKS, N. 1907 [1908.04.07]. New tropical American Neuroptera. - Proceedings of the Entomological Society of Washington 9: 30-34.

Banks, N. 1911: Notes on African Myrmeleonidae. -- Annals of the Entomological Society of America 4:1-[31].

BANKS, N. 1937: Neuropteroid insects from Formosa. - Philippine Journal of Science 62: 255-291.

CHANDRA, K. \& SHARMA, R. M. ????: Check List of Indian Neuropterids (Insecta: Megaloptera; Raphidioptera; Neuroptera). - Zoological Survey of India, Central Zone Regional Centre Jabalpur- 482 002, Madhya Pradesh Last accessed: 15. April, 2020.

CoVELL, C. V., JR. 1989: Aggregation behavior in a Neotropical owlfly, Cordulecerus maclachlani (Neuroptera: Ascalaphidae). - Entomological News, Philadelphia 100: 155-156.

Doвosz, R. 2007: New faunistics data on Osmylidae (Neuroptera) from Turkey. - Rocznik Muzeum Górnoslaskiego w Bytomiu, Entomologia [=Annals of the Upper Silesian Museum in Bytom, Entomology] 14-15: 35-37.

Dobosz, R.; ÁBrAHÁm, L. 2007. New data to the Turkish ascalaphid fauna (Neuroptera: Ascalaphidae). Rocznik Muzeum Górnoslaskiego w Bytomiu, Entomologia [=Annals of the Upper Silesian Museum in Bytom, Entomology] 14-15: 13-27.

Dobosz, R. ÁbrahÁm, L. 2009: Contribution to the knowledge of the Turkish tail-wings (Neuroptera: Nemopteridae). - Natura Somogyiensis 15: 113-126.

Esben-Petersen, P. 1913: H. Sauter's Formosa-Ausbeute. Planipennia II, Megaloptera and Mecoptera. - Entomologische Mitteilungen 2: 222-228, 257-265.

Esben-Petersen, P. 1916. Notes concerning African Myrmeleonidae I. - Arkiv för Zoologi 10(15): 1-22.

Esben-Petersen, P. 1931: Neue und wenig bekannte Neuropteren aus Süd-Angola. - Revue Suisse de Zoologie 38: 89-95.
Esben-Petersen, P. 1936: Neuroptera from Belgian Congo. - Revue Suisse de Zoologie 43: 199-206.

FRASER, F. C. 1927: Notes on a collection of Ascalaphidae from the Federated Malay States. - Journal of the Federated Malay States Museums 13: 257-259.

GHosH, S. K. 1988: Contribution to the taxonomical studies of Neuroptera (suborder Planipennia) from eastern India. II. Family Ascalaphidae. Records of the Zoological Survey of India 85: 163-191.

GHosH, S. K. 2000: Neuroptera fauna of north-east India. Records of the Zoological Survey of India, Miscellaneous Publications, Occasional Paper 184:xiii+1-179.

GHosh, S. K.; SEN, S. 1977: Check-list of Indian Planipennia (Order Neuroptera). - Records of the Zoological Survey of India 73: 277-326.

Gomes-Filho, A. 2000: Aggregation behavior in the Neotropical owlfly Cordulecerus alopecinus (Neuroptera: Ascalaphidae). - Journal of the New York Entomological Society 108: 304-313.

HANDSCHIN, E. 1960: Beiträge zu einer Revision der Mantispiden (Neuroptera). II Teil. Mantispiden des „Musée Royal du Congo Belge”, Tervuren. - Revue de Zoologie et de Botanique Africaines 62: 181-245.

Hassan, M. A.; Oswald, J. D.; ZIA, A.; LIU, X.-Y. 2019: Neuropterida (Insecta: Megaloptera, Raphidioptera, Neuroptera) of Pakistan: a catalogue and faunistic review. - Zootaxa 4686: 497-541.

HeCkman, C. W. 2017: Neuroptera (including Megaloptera). Encyclopedia of South American aquatic insects. Illustrated keys to the known families, genera, and species in South America. - Springer. $x v i+621$ pp.

Hogue, C. L.; Penny, N. D. 1988: Aggregations of Amazonian ow[l]flies (Neuroptera: Ascalaphidae: Cordulecerus). - Acta Amazonica 18: 359-361.

HöLzEL, H. 1975: Revision der Netzflügler-Unterfamilie Crocinae (Neuroptera: Nemopteridae). - Entomologica Germanica 2: 44-97.

HöLzEL, H. 1999: Die Nemopteriden (Fadenhafte) Arabiens: ein Beitrag zur Kenntnis der Neuropterida der Arabischen Halbinsel (Neuropterida: Neuroptera: Nemopteridae). - in Aspöck, H. (ed.). Neuropterida: Raphidioptera, Megaloptera, Neuroptera. Kamelhälse, Schlammfliegen, Ameisenlöwen. Stapfia 60: 129-146.

JoNES, J. R. 2014: Taxonomic revisions of six genera of entire-eyed owlflies (Ascalaphidae: Haplogleniinae), and first large-scale phylogeny of the owlflies. - A Dissertation Submitted to the Office of Graduate and Professional Studies of Texas A\&M University in partial fulfillment of the requirements for the degree of Doctor of Philosophy $1088 \mathrm{pp}$.

KIMmins, D. E. 1949: Notes on Ascalaphidae in the British Museum collections, with descriptions of new species. - Annals and Magazine of Natural History (12)2: 1-29.

Krivokhatsky, V.; HaJiesmailian, A.; Mirmoayedi, A.; Khabiev, G.; Dobosz, R.; OstroverkHova, M. 2017. Palpares turcicus KoçAK, 1976: - new name for Iranian fauna and its place in the P. libelluloides species group (Neuroptera: Myrmeleontidae). Proceedings of the Zoological Institute [=Труды Зоологического Института; =Trudy Zoologicheskogo Instituta] 321(4): 377-402.

MANSELL, M. W. 1996: The antlions of southern Africa (Neuroptera: Myrmeleontidae): genus Palparellus Navás, including extralimital species. - African Entomology 4: 239-267.

MANSELL, M. W. 2000: Neuroptera (Insecta). in Kirk-Spriggs, A. H.; Marais, M. (eds.). Dâures-biodiversity of the Brandenberg Massif, Namibia. Cimbebasia Memoir 9:163-176.

MANSELL, M. W. 2002: Monitoring lacewings (Insecta: Neuroptera) in southern Africa. in Sziráki, G. (ed.). - Neuropterology 2000. Proceedings of the Seventh International Symposium on Neuropterology (6-9 August 2000, Budapest, Hungary). Acta Zoologica Academiae Scientiarum Hungaricae 48 (Suppl. 2): 165-173.

MANSELL, M. W. 2004: Antlions of southern Africa: Annulares nov. gen. (Neuroptera, Myrmeleontidae, Palparini) including two new species, with comments on the tribe Palparini. in Aspöck, U. (sci. ed.). Entomologie und Parasitologie. Festschrift zum 65. Geburtstag von Horst Aspöck. - Denisia 13: 201-208. 
MANSELL, MeRVYN W., 2018: Antlions of southern Africa: genus Crambomorphus McLachlan, 1867, including extra-limital species (Neuroptera: Myrmeleontidae: Palparinae: Palparini), Zootaxa 4382 (3), pp. 465-500: 482-488

MANSELL, M. W.; OsWALD, J. D. 2020: Neuropterida of South Africa. URL: http://lacewing.tamu.edu/Faunas/SouthAfrica. Last accessed [last accessed 19.04.2020].

MCLACHLAN, R. 1868 [1867.??.??]: New genera and species, \&c., of neuropterous insects; and a revision of Mr. F. Walker's British Museum Catalogue of Neuroptera, part ii. (1853), as far as the end of the genus Myrmeleon. - Journal of the Linnean Society of London, Zoology 9: 230-281.

MCLACHLAN, R. 1873: An attempt towards a systematic classification of the family Ascalaphidae. - Journal of the Linnean Society of London, Zoology 11: 219-276.

MiCHEL, B. 2019: Revision of the genus Disparomitus van der Weele, 1909 with descriptions of four new species (Neuroptera, Ascalaphidae). - Zootaxa 4551 (1): 001-039.

Michel, B.; MANSELL, M. W. 2018: A new genus and species of owlfly from eastern and southern Africa (Neuroptera: Ascalaphidae). European Journal of Entomology 413: 1-12.

MonerRAT, C. \& ÁBRAHÁM, L. 2020: Owlflies from Jordan (Neuroptera, Ascalaphidae) - Alpin entomology 4: 139-150.

MonserRAt, V. J.; TRIVIÑo, V. 2013: Atlas de los neurópteros de la Peninsula Ibérica e Islas Baleares (Insecta, Neuroptera: Megaloptera, Raphidioptera, Planipennia). - Monografías de la Sociedad Entomológica Aragonesa 13:1-154.

NAvÁs, L. 1911: Algunos neurópteros del Museo de Madrid. - pp. 91-98. Asociación Española para el Progreso de las Ciencias. Congreso de Valencia [held 1910]. Tomo V, Sección $4^{\mathrm{a}}$, Ciencias Naturales. Madrid, Imprenta de Eduardo Arias, 1911.

NAvÁs, L. 1912a: Bemerkungen über die Neuropteren der Zoologischen Staatssammlung in München. II. - Mitteilungen der Münchener Entomologischen Gesellschaft 3: 20-26.

NAVÁs, L. 1912b: Bemerkungen über die Neuropteren der Zoologischen Staatssammlung in München. III. - Mitteilungen der Münchener Entomologischen Gesellschaft 3: 55-59.

NAvÁs, L. 1912c: Sinopsis de los Ascaláfidos (Ins. Neur.). - Arxius de l'Institut de Ciències, Institut d'Estudis Catalans, Secció de Ciències 1: 45-143.

NAvÁs, L. 1912d: Myrméléonides (Ins. Névr.) nouveaux ou peu connus. - Annales de la Société Scientifique de Bruxelles 36(pt. 2): 203-248.

NAvÁs, L. 1913: Les Névroptères. - Annales d'Histoire Naturelle, Délégation en Perse, Paris 2: 13-16.

NAvÁs, L. 1914: Voyage de Ch. Alluaud et R. Jeannel en Afrique Orientale (1911-1912). - Résultats scientifiques. Insectes Névroptères. I. Planipennia et Mecoptera. Paris. 52 pp.

NAvÁs, L. 1909-1915 [1914.08.25]: Neurotteri Planipenni, raccolti da S. A. R. la Duchessa d'Aosta sulla regione dei grandi laghi dell'Africa equatoriale. - Annuario del [R.] Museo Zoologico della R. Università di Napoli (N.S.)4(12): 1-4.

NAvÁs, L. 1924: Algunos insectos del Museo de París. 2.a serie [lla]. Brotéria (Zoológica) 21: 99-114.

NAVÁs, L. 1928: Insectos del Museo de Estocolmo. - Revista de la Real Academia de Ciencias Exactas Fisicas y Naturales de Madrid 24: 28-39.

NAvÁs, L. 1931: Insectes du Congo Belge (Série V). - Revue de Zoologie et de Botanique Africaines 20: 257-279.

Needham, J. G. 1909: Notes on the Neuroptera in the collection of the Indian Museum. - Records of the Indian Museum, Calcutta 3: 185-210.

Pantaleoni, R. A., Badano, D, Aspöck, U. \& Aspöck, H. 2013: Ascalaphus festivus (Rambur, 1842) in Sardinia, a new genus of Ascalaphidae for Europe (Neuroptera). - Biodiversity Journal 4: 179-182.

Penny, N. D. 1977 [1978.09.15]: Lista de Megaloptera, Neuroptera e Raphidioptera do México, América Central, ilhas Caraíbas e América do Sul. - Acta Amazonica 7(4)(Suplemento): 1-61.

Penny, N. D. 1981: Neuroptera of the Amazon Basin. Part 3. Ascalaphidae. - Acta Amazonica 11: 605-651.
Penny, N. D.; Adams, P. A.; Stange, L. A. 1997: Species catalog of the Neuroptera, Megaloptera, and Raphidioptera of America North of Mexico. - Proceedings of the California Academy of Sciences (4)50: 39-114.

Prost, A. 2010: Patterns of distribution of the Palparini (Neuroptera: Myrmeleontidae: Palparinae) in the northern half of Africa: faunal transitions and regional overlaps. - Pp. 257-266 Devetak, D.; Lipovšek, S.; Arnett, A. E. (eds.). Proceedings of the 10th International Symposium on Neuropterology (22-25 June 2008, Piran, Slovenia). University of Maribor, Maribor, Slovenia. $307 \mathrm{pp}$.

Prost, A. 2013: The genus Ascalaphus (Fabricius, 1775) (Neuroptera, Ascalaphidae) in Africa. - Açoreana, Revista de Estudos Açoreanos, Suplemento 9: 57-72.

RAmBuR, [J.] P. 1842: Histoire naturelle des insectes, névroptères. Librairie encyclopédique de Roret. Fain et Thunot, Paris. [xviii] + $534 \mathrm{pp}$.

SHETLAR, D. J. 1977: The biosystematics of the Nearctic Ascalaphidae (Insecta: Neuropteroidea: Planipennia), with notes on biology and morphology. - Ph.D. dissertation. Pennsylvania State University, University Park, Pennsylvania, USA. $x+246$ pp.

StANGE, L. A. 1989: Review of the New World Dimarini with the description of a new genus from Peru (Neuroptera: Myrmeleontidae). Florida Entomologist 72: 450-461.

StANGE, L. A.; WANG, H.-Y. 1997: Checklist of the Neuroptera of Taiwan. - Taiwan Sheng Li Bo Wu Guan [=Journal of the Taiwan Museum] 50: 47-56.

StANGE, L. A. 2000: A checklist and bibliography of the Megaloptera and Neuroptera of Florida. URL: http://www.fsca-dpi.org/Neuroptera/Neuroptera_of_Florida.htm Last accessed [last accessed 19.04.2020].

StITZ, H. 1912: Palpares aus der Sammlung des Berliner Museums. Mitteilungen aus dem Zoologischen Museum in Berlin 6: 103116.

SZIRÁKI, GY. 1998: An annotated checklist of the Ascalaphidae species known from Asia and from the Pacific Islands. - Rovartani Közlemények [=Folia Entomologica Hungarica] (N.S.)59: 57-72.

SzIRÁKI, G. 2000: Data to the knowledge of the Asian Ascalaphidae (Neuroptera), with description of a new subspecies. Rovartan Közlemények [=Folia Entomologica Hungarica] (N.S.)61: 87-93.

SzIRÁKI, GY. 2011: Order Neuroptera, family Nemopteridae. - Pp. 66-71 in van Harten, A. (ed.). Arthropod fauna of the United Arab Emirates. Vol. 4. Dar Al Ummah, Abu Dhabi.

TAuber, C. A.; Simmons, Z.; TAuber, A. J. 2019: Type specimens of Neuropterida in the Hope Entomological Collection, Oxford University Museum of Natural History. - ZooKeys 823: 1-126.

TJEDER, B. 1967: Neuroptera-Planipennia. The Lace-wings of Southern Africa. 6. Family Nemopteridae. Pp. 290-501 in Hanström, B.; Brinck, P.; Rudebec, G. (eds.). - South African Animal Life. Vol. 13. Swedish Natural Science Research Council, Stockholm.

TJEDER B., HANsson C. 1992: The Ascalaphidae of the Afrotropical Region (Neuroptera). 2. Revision of the tribe Ascalaphini (subfam. Ascalaphinae) excluding the genus Ascalaphus Fabricius. - Entomologica Scandinavica, Supplement 41: 171-237.

VAN DER WEELE H.W. 1909: Ascalaphiden monographisch bearbeitet. Collection Zoologique Selys Longchamps 8: 1-326.

WALKER, F. 1853: List of the specimens of neuropterous insects in the collection of the British Museum. Part II.-(Sialidae--Nemopterides). - British Museum, London. [iii] + 193-476 pp.

WANG, X.-L.; ZHAN, Q.-B.; WANG, A.-Q. 2018: 中国动物志 [=Fauna Sinica]. 昆虫纲 第六十八卷 [=Insecta Vol. 68]. 脉翅目 [=Neuroptera], 蚁蛉总科 [=Myrmeleontoidea]. Science Press, Beijing. [viii] $+x$ $+285 \mathrm{pp}$.

Whittington, A. E. 2002: Resources in Scottish Neuropterology. in Sziráki, G. (ed.). Neuropterology 2000. Proceedings of the Seventh International Symposium on Neuropterology (6-9 August 2000, Budapest, Hungary). - Acta Zoologica Academiae Scientiarum Hungaricae 48(Suppl. 2): 371-387. 
